
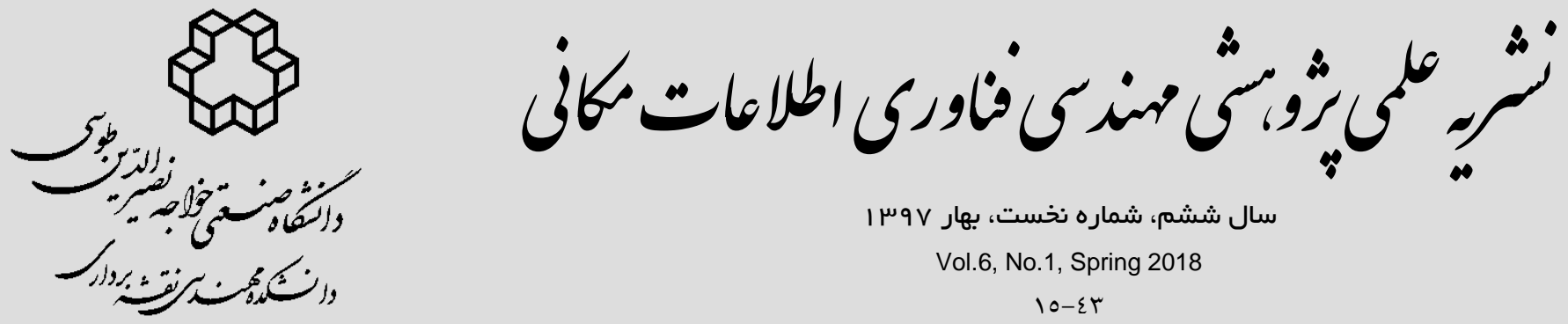

I سو سال ششم، شماره نخست، بهار

Vol.6, No.1, Spring 2018

$10-\varepsilon r$

الكوريتمى جديد و كارا براى جايابى و بوشش سهبعدى رباتهاى يرنده در فضاى بردارى

على اصغر حيدرى '، فريد كريمى يور"re

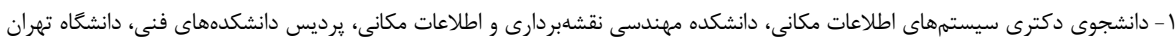

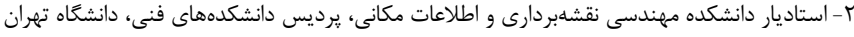

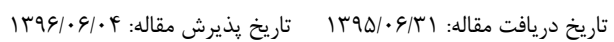

جكيده

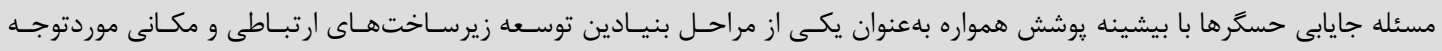

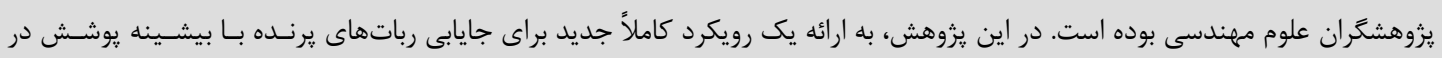

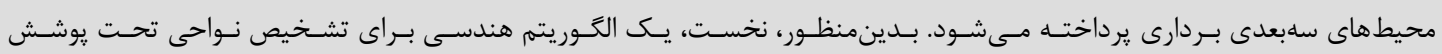

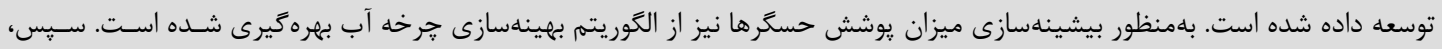

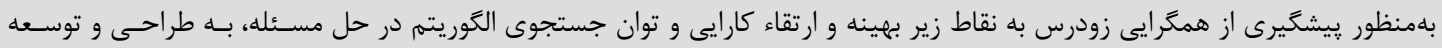

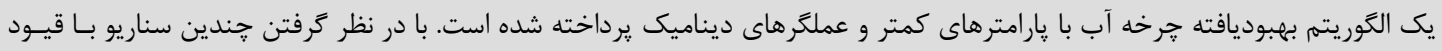

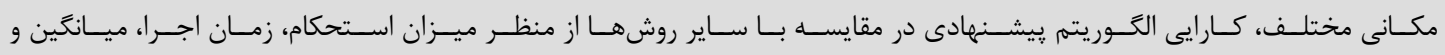

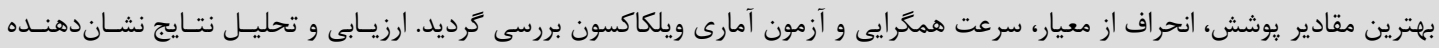

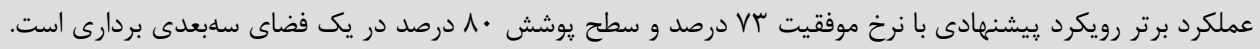

كليد وازهها: ربات يرنده، جايابى، يوشش، فضاى بردارى، بهينهسازى، الگَريته خرخه آب. 
مقرونبهصرفه نيست. به همين دليل، مىبايست تعادلى

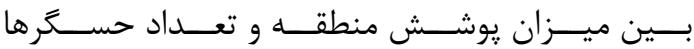
در نظر گرفته شود. براى مثال، شكل (1) مجموعهاى از رباتهـاى يرنـده را در يـك ســـاريوى فرضـى يوشـش سلبعدى نمايش مى دهد. در ايسن شـكل محـدودههـاى

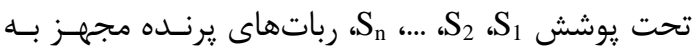

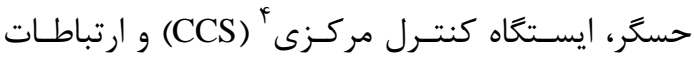

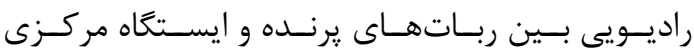
نمايش داده شده است. مسئله جايابى و بيشينهسازى يوشش با كمك رباتهاى يرنــده در تحقيقــات مــرتبط بــا علـوم رباتيـــ نيـز مطرح بوده و براى كاربردهـايى نظيـر : يـايش و نظــارت

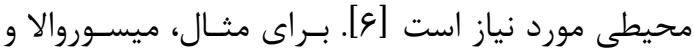
همكاران بر مبناى يك مدل رسترمبنا بـه حــل مســـله

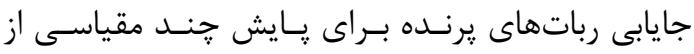

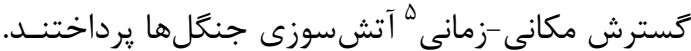

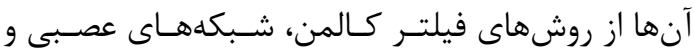

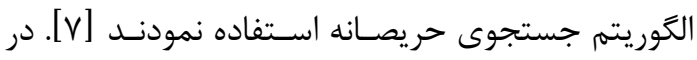
تحقيق ديخرى، به حل مسئله يوشش منطقه بـا كمـك

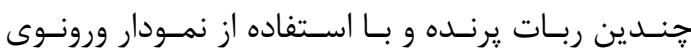

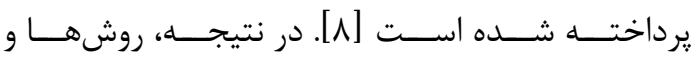

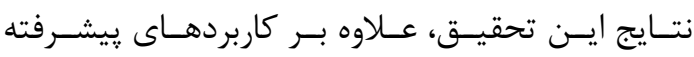

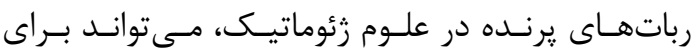

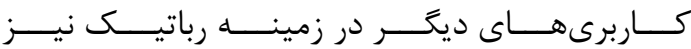
قابل استفاده باشد.

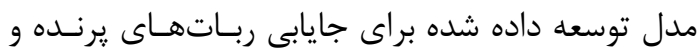
حداكثرسازى يوشـش شـبكه مطـرح در ايـن يـرّوهش بر اساس مفاهيم مدل هـاى يوششىى مطـرح در زمينــه يوشش و جايابى حسگرها در موضوع شبكههاى حسـگر

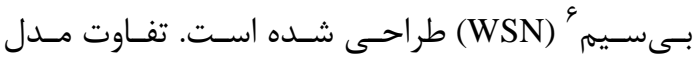
بهينهسازى مطرح در اين يزوهش با تحقيقـات ييشـين

${ }^{4}$ Central control station

${ }^{5}$ Spatio-temporal

${ }^{6}$ Wireless sensor network
| - مقدمه

با رشد روزافـزون علـم رباتيـك، بــهــرور بـهـــاركيرى، برنامهريزى، مسـيريابى و كنتــرل ربـاتهـا و همجنــين

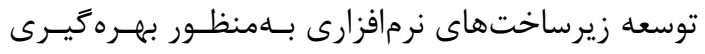

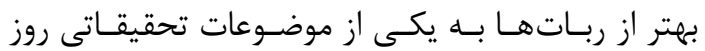

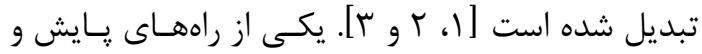
مراقبت از تأسيسات حساسى همجون تأسيسات نفتى و

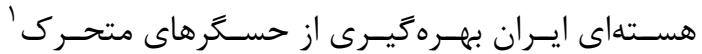

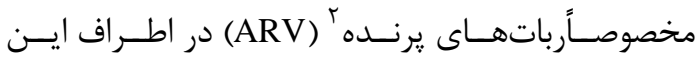

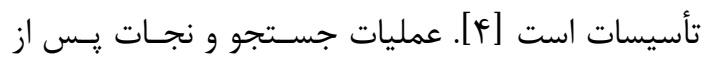

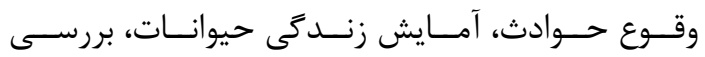
فعاليتهاى آتشفشان ها و وايشهاى زيستمحيطى نيز نمونههايى ديخر از كاربردهاى روزافـزون ايسن ربـاتهـا

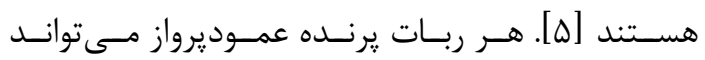

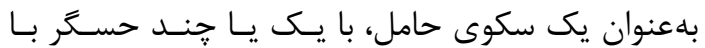

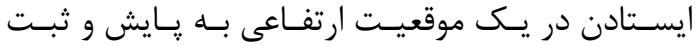

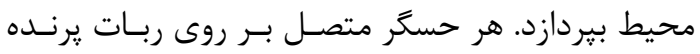

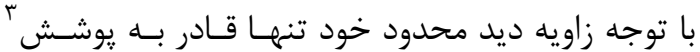
بخش خاصى از سطوح قابل ديد منطقـهـ خواهـد بـود و ميزان يوشش كل منطقه، مىتوانـد از مجمـوع سراسـر

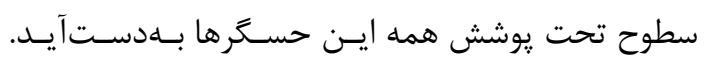

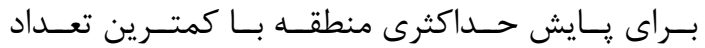
ربات يرنده، هر ربات بايد بهَّونهاى مكانيابى شـود كـهـ

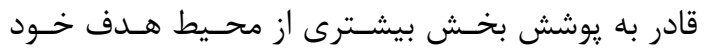
باشد. منطقه تشخيص هـر حسـعر تحست تـأثير قـدرت سيخَنال آن و وجود موانـع محيطـى محسدود مسى شــود. كرههاى حسگرى مى بايست در مناطقى تعبيه شوند كه

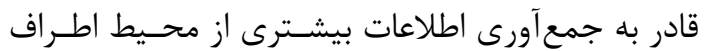

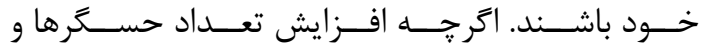

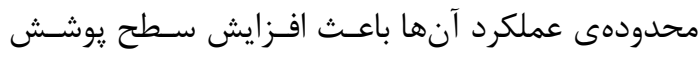

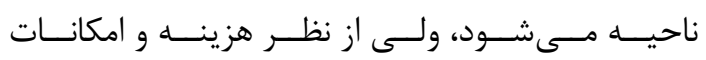

\footnotetext{
${ }^{1}$ Mobile sensors

${ }^{2}$ Aerial robotic vehicle

${ }^{3}$ Coverage
} 
بــه توسـعه روشـى بـراى محاسـبـه مسـتقيمم مسـاحت

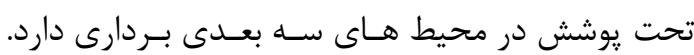

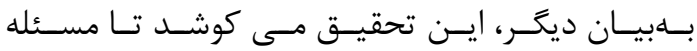

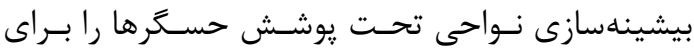

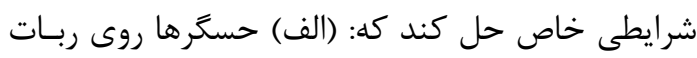

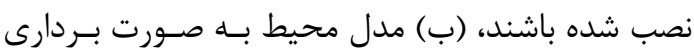

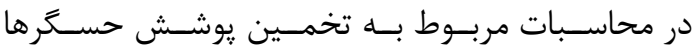

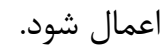

در زمينه شبكههاى حسگر بىسيم در آن است كـه در

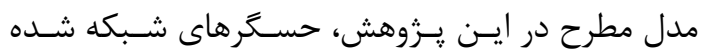

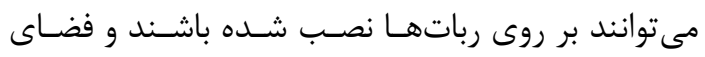

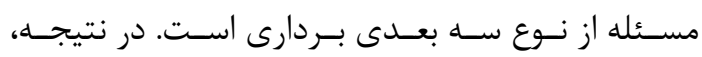

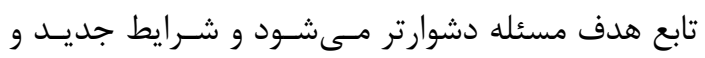
قيود ديناميكى به مسئله بهينهسازى افزوده خواهد شد.

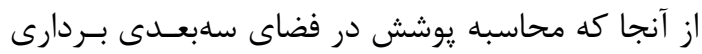
مدنظر است نه رسترى، محاسبه تابع هدف مسئله نيـاز $\mathrm{ARV}_{2}$

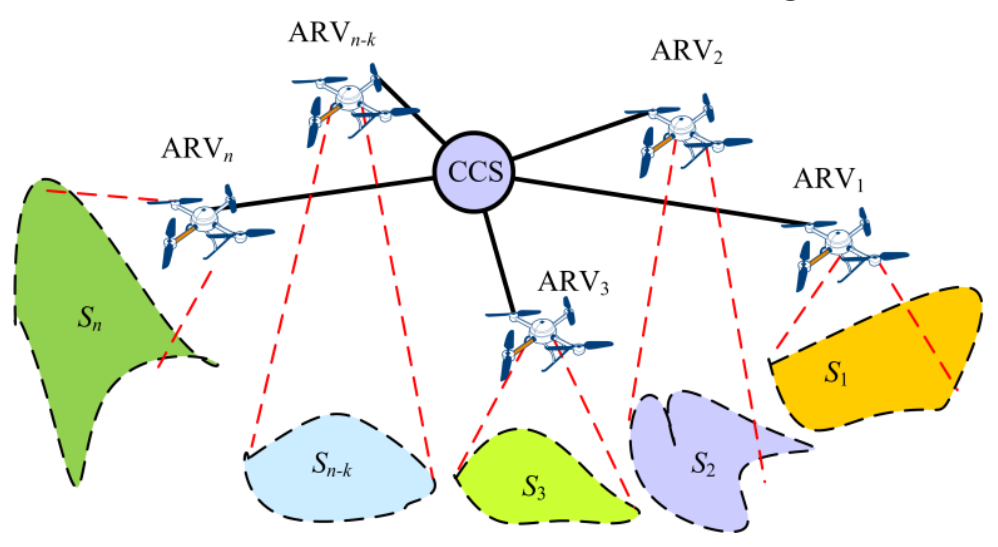

شكل ا: توصيف سناريوى جايابى رباتهاى يرنده براى استقرار در موقعيت بهينه و محاسبه يوشش بيشينه در يك فضاى سي سه بعدى

با محدوديت هاى اجرايى و هزينههاى عمليـات سـاز گار

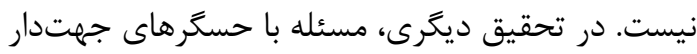

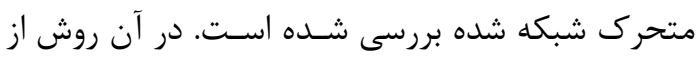

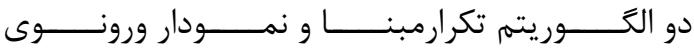

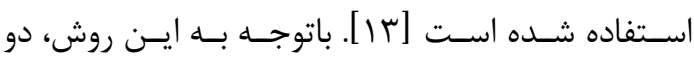
الگوريتم داراى ثيجيدگى محاسباتى بالا بودهاند و نتايج

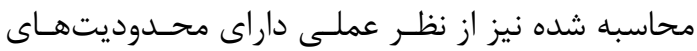

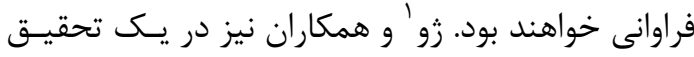

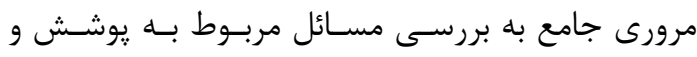

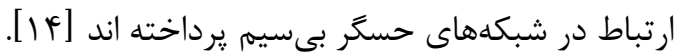

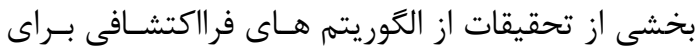

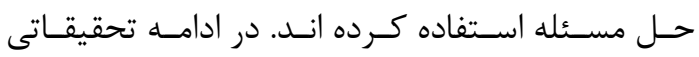

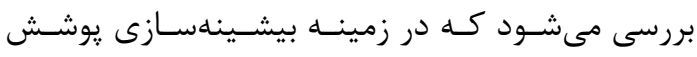

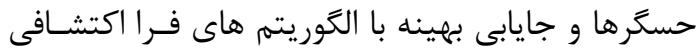

${ }^{1}$ Zhu
تاكنون اين مسئله با مدلسازى و روش هاى مطـرح در

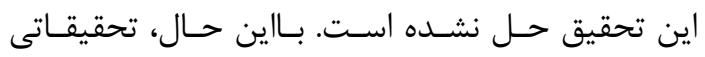
ييرامون حسكرهاى ثابت با حركات جزئسى و همجنـين حسگرهاى متحرك در فضاى دوبعدى انجام شده است

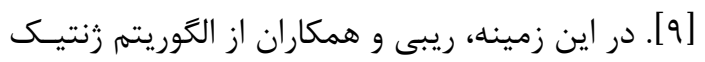

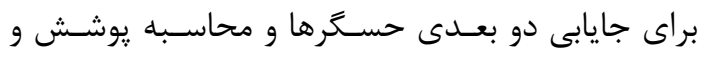

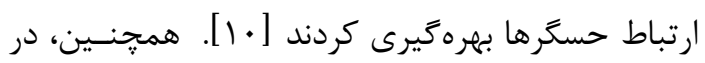
تحقيق ديگرى، با اسـتفاده از يـك الخـوريتم حريصـانه، يوشش سراسرى شبكههاى دوبعدى با گرههاى متحرى

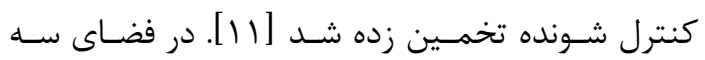
بعدى، آلام و همكاران يوشـش بيشـينه حسـحرها را در

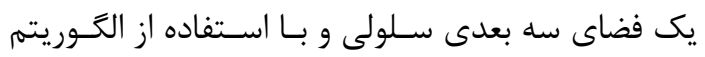
جايابى تصادفى محاسبه كردند [T I ]. آنها بيان كردنـد كه با روش توسعه داده شده بايد حسگر ها را بــه تعـداد بالا و بهصورت تصادفى در سراسر فضاى سلولى مسـئله

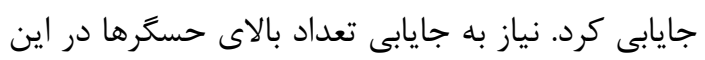


فئمت ABC ABC

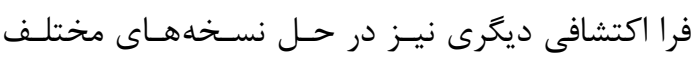

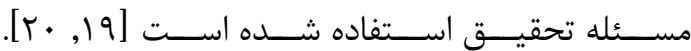

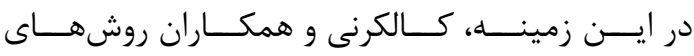

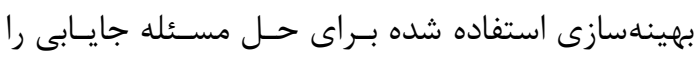
بهصورت جامع مرور كردند [Ir]. تيساى و همكاران نيز

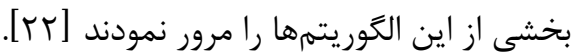
يس از بررسى تحقيقات متعدد، مشاهده مسى كـردد كـهـ در زمينه مرتبط شبكدهاى حسكر بىسيم، سـناريوهاى

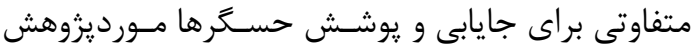
واقع شده است. در بسـيارى از تحقيقـات، از مـدل داده

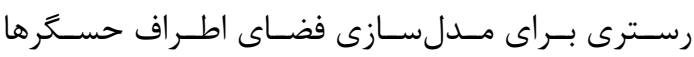

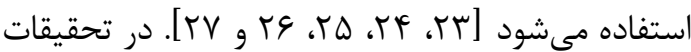

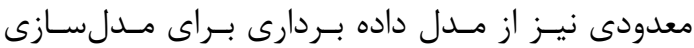

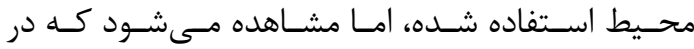

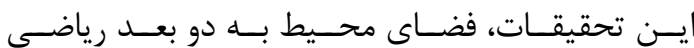

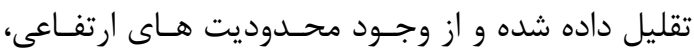

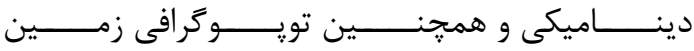

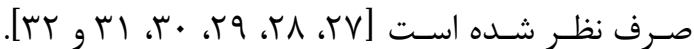

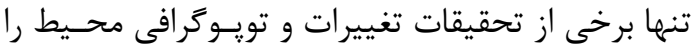
در طراحى مسئله يوشش حسكرها لحاظ كردهاند كه باز

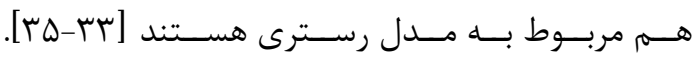
در اين تحقيقات از مدل رقمسى سـطح زمسين (DSM)

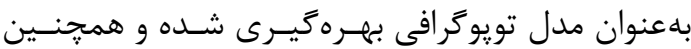

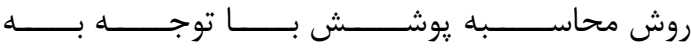
مدل رقومى سطح زمين بهبود داده شده است. با اينكه تحقيقاتى در زمينه اين مسئله انجام شـده، امـا

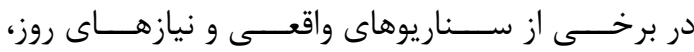
مدل بردارى سه بعدى فضا در دست اسـت و برخـى يـا همه حسكرها بايد بر روى ربـات برنــده متصـل باشـــد.

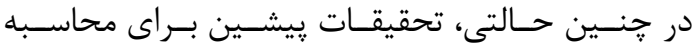

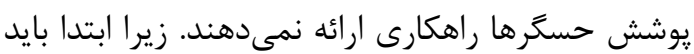
راهكارى را براى محاسبه يوشش در يك محيط بردارى ريكاري

${ }^{3}$ Digital surface model

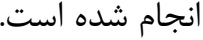

بر اساس مطالعات پِيشين، يكى از رويكردهـاى كـارا و

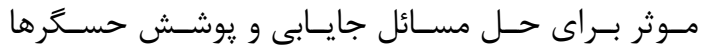

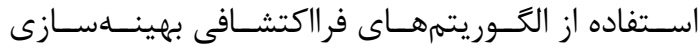

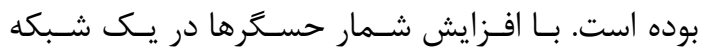
حسكَ بىسيم، سطح تحت يوشش افزايش خواهد يافت

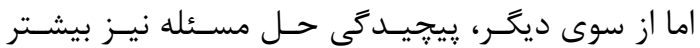
خواهد شد. از منظر كارفرما نيز، افزايش تعداد حسكرها

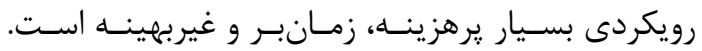
ازاين روى، يكى از رويكردهاى فراكير، سريع و كارا براى

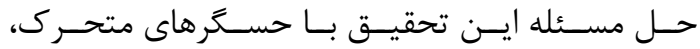

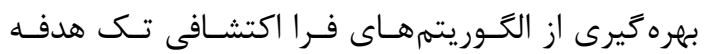

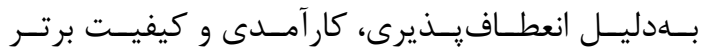
ياسخهاى بهدست آمده بوده است. تحقيقات فراوانسى در

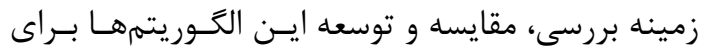

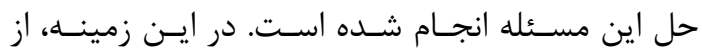

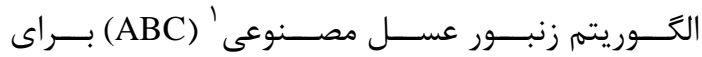

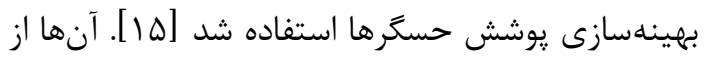
مدل تشخيص احتمالى براى حسكرها استفاده نمودنـد.

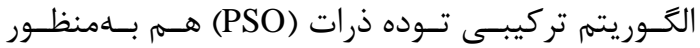
جايابى حسكرهاى همه جهتى دوبعدى با مدل يوشـش التش

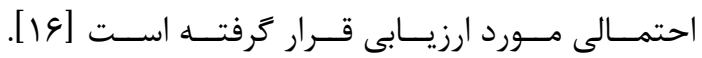

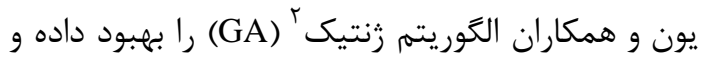

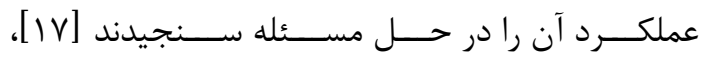
اما در اين تحقيـق، مشـابه بسـيارى از مقـالات مشـابه،

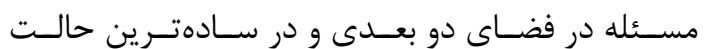

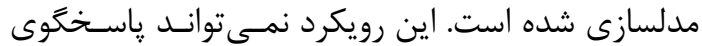

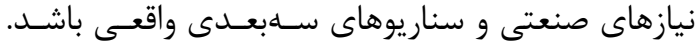
اخيراً نيز عملكرد الكوريتم بهينهسازى شبه مغناطيسى نيــز در تخمــين يوشــش حســــرها در اين تحقيق، يك مدل تشخيص احتمالى جديـد نيـز

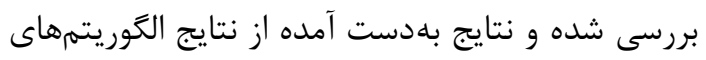

${ }^{1}$ Artifitial bee colony

${ }^{2}$ Genetic algorithm 
بيشينه يوشـشَ (MCSDP) بـا رويكـردى جديـد و بـا

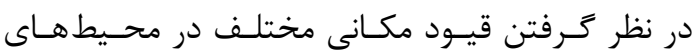

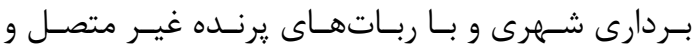

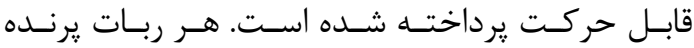

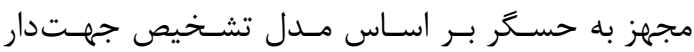

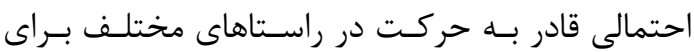

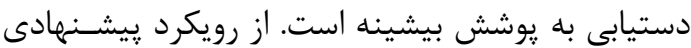

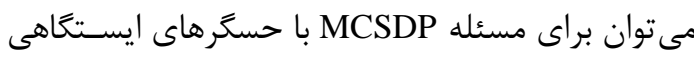
نيز بهرهگيرى كرد. بهمنظور حل اين مسئله، بـه دليـل مهل

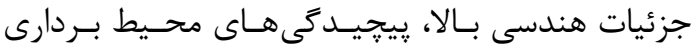

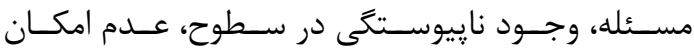

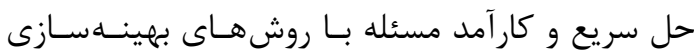

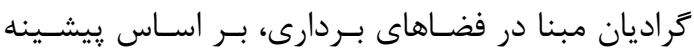
تحقيق، به تخمين ميزان بيشينه يوشش بـا اسـتفاده از

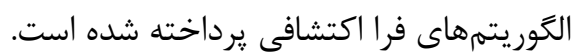

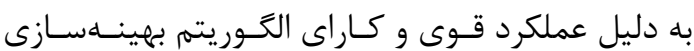

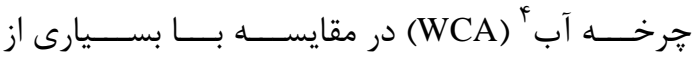

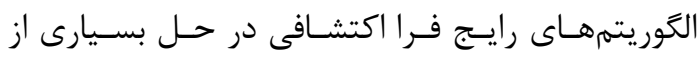

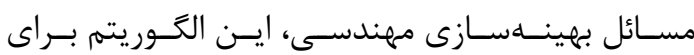
حل مسئله انتخاب شد. بدينمنظور، براى ارتقاء عملكرد

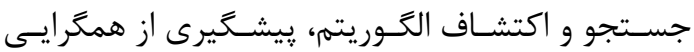

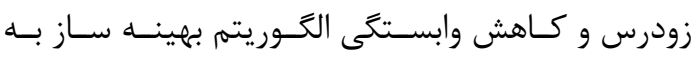

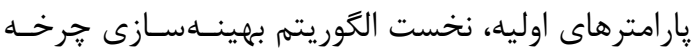

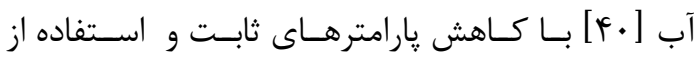

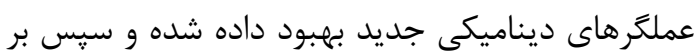
اساس معيارهايى نظير اسـتحكام محاسـباتى، بهتـرين،

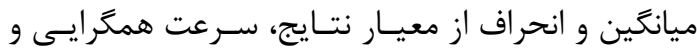

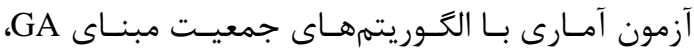
كرى خاكسترى هُ (GWO)، رقابت استعمارى (ICA) و

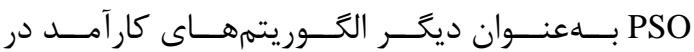
تحقيقات مرتبط مقايسه مىشود.

\footnotetext{
${ }^{3}$ Maximum coverage sensor deployment problem

${ }^{4}$ Water cycle optimization algorithm

${ }^{5}$ Grey wolf optimizer

${ }^{6}$ Imperialist competitive algorithm
}

سه بعدى توسعه داد. سيس محدوديتهاى مربـوط بــهـ

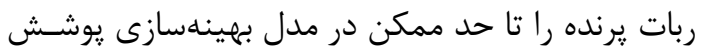
و جايابى اعمال نمود. در نهايت نيز بايد ياسخهاى بهينه مدل را با يك الكوريتم بهينهسازى كارا ييدا كرد.

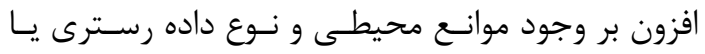
بردارى كه مىتواند براى مدل سازى فضاى تحت يوشش

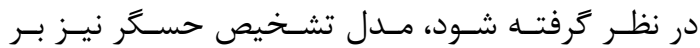

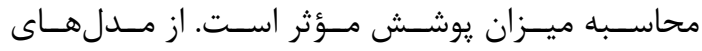

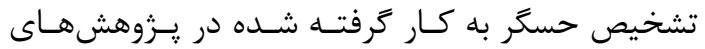
ييشين مى توان به مدل تشخيص دايرهاى ساده و مـدل

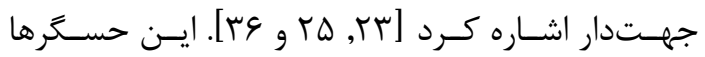
مى توانند در محيط مستقر شوند و يا باصورت متحـرك باشند و بهصورت نقطهاى و محدودهاى، جهت مدار و همه

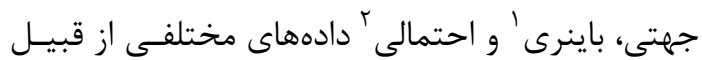
دما، فشار، نور، رطوبت، نوع خاك، حركت وسايل نقليه،

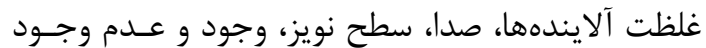

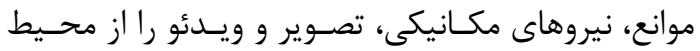

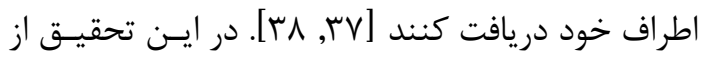
يك مـدل تشـخيص احتمـالى موجـود بــراى حسـرهـا استفاده شده است [وب]. مسئله محاسبه جايابى و يوشش با مدل هاى بردارى سه

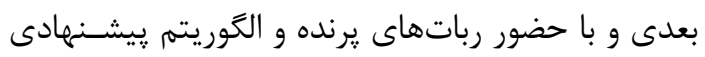

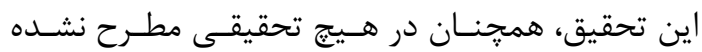
است. زيـرا عـلاوه بـر روش جديـد محاسـبه يوشـش و

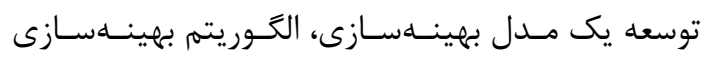
ييشنهادى نيز براى نخستين بار ارائه مىشود. بـا آنكـهـ

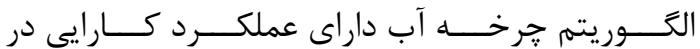
حل مسائل مقيد بهينه سـازى بـوده، تـاكنون عملكـرد

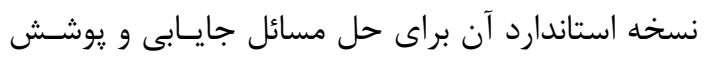
ارزيابى نشده است. در اين تحقيـق، بـه حــل مسـئله جايـابى حســرها بـا

\footnotetext{
${ }^{1}$ Binary

${ }^{2}$ Probable
} 
تحليل نتايج الكوريتمهاى مختلف در حـل ايـن مسـئله

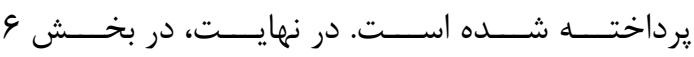

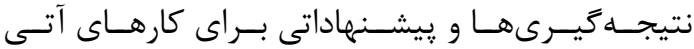

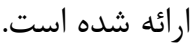

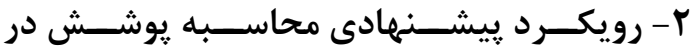
محيطهاى سهبعدى بردارى

در اين بخش، يك رويكرد جديد براى محاسبه يوشـش

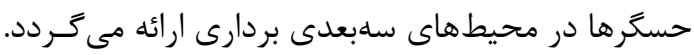

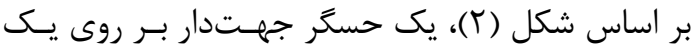

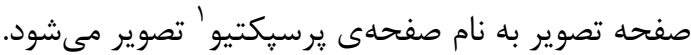
محدودهى زاويه عملكرد حسگر نيز بهصورت يك دايسره

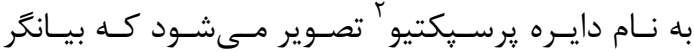
ميدان ديد حسكر است. بر اين اساس، براى محاسـبهى

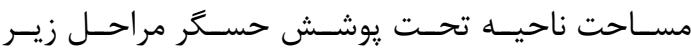

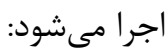
1 - حذف جندضلعى هاى پشت به حسگ r- حذف جندضلعىهاى يشت صفحهى يرسيكتيو r- حذف جندضلعى هاى خارج از محدودهى فاصله

$$
\text { حسگر }
$$

ץ- تصوير كردن جندضـلعى هــا بـر روى صـفحهى يرسيكتيو و برهمنهلى آنها با يكديكر

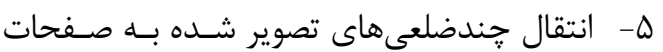
جندضلعىهاى سهبعدى خود

\section{r-1 - حذف جندضلعى هاى پشت به حسگر} در اين مرحله، جندضـلعىهـايى حـذف مـىشـوند كـهـ

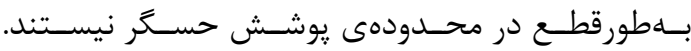

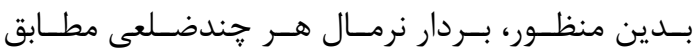
رابطه ( ) محاسبه شده و با بردار اتصال جندضـلعى بـه حسگر مقايسه مىشود.

$$
\vec{N}=\operatorname{cross}\left(v_{2}-v_{1}, v_{3}-v_{2}\right) \quad \text { (1) }
$$
كه در اين فرمول از ضرب خارجى سه نقطـهـى نخســ

\footnotetext{
${ }^{1}$ Perspective plane

${ }^{2}$ Perspective circle
}

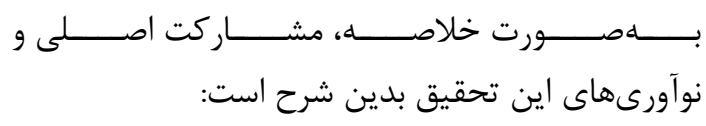

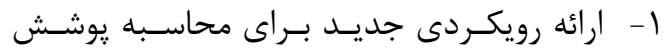

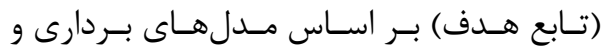

ساdبعدى (بخش r)

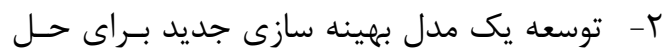

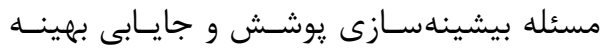

$$
\text { رباتهاى يرنده (بخش أ) }
$$

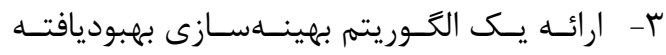

بر مبناى الكوريتهم بهينهسازى جرخه آب بـراى

حل مدل توسعه داده شده (بخش ؟)

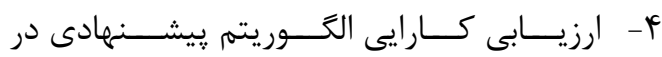

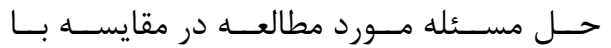

الگوريتم استاندارد و ديگر الخوريتم ها

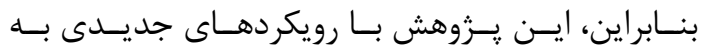

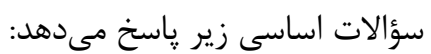

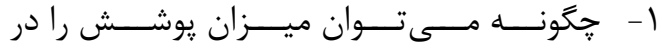

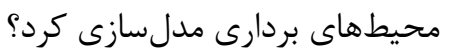

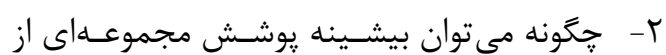

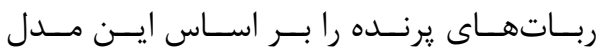

محاسبه كرد؟

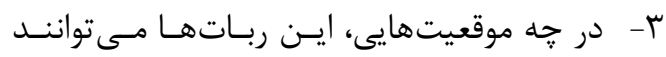

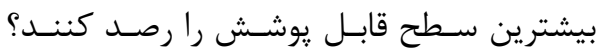

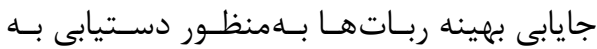

حداكثر مقدار يوشش جَگُونه محاسبه مىشود؟

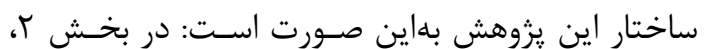
رويكرد يِيشنهادى براى محاسبه يوشش در محيطهـاى سـهبعـدى بـردارى تشـريح شـده اسـت. در بخــش با،

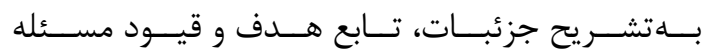

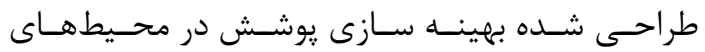

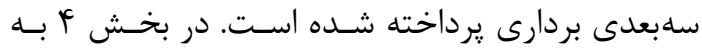
توصيف گامهاى اصلى و ساختار الكوريتم بهينـهسـازى

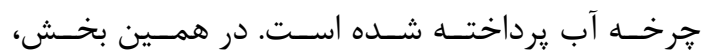

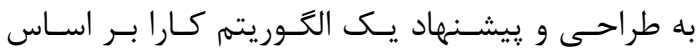
اين الكوريتم پرداخته شده است. در بخش هـ به به ارائسه و 


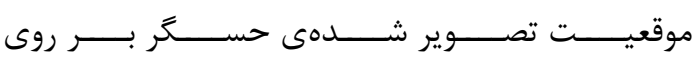

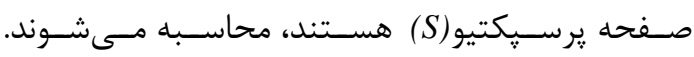

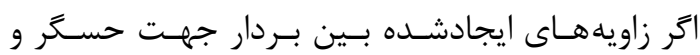

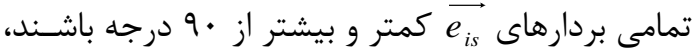

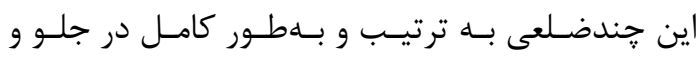

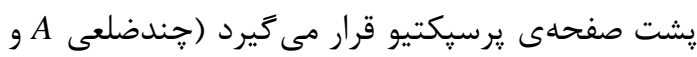

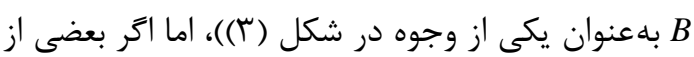

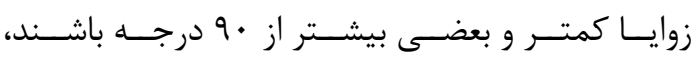

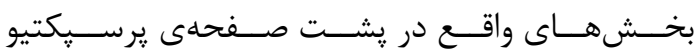

حذف مى گردد (وجوه جندوجهى C در شكل (r)).

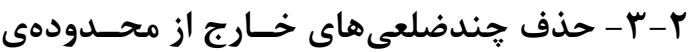
فاصلهى عملكرد حسكر

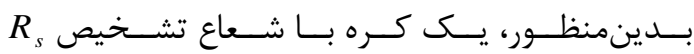
بهعنوان محدودهى عملكرد حسگر در نظر گرفتـه شـده

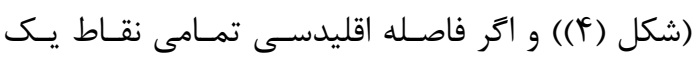
جندضلعى (باعنوان يكى از وجوه جندوجهى) با حسگر، dis

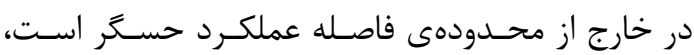

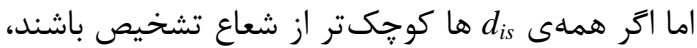
جندضلعى قابل تشخيص خواهد بود. در جندوجهى زهــاى

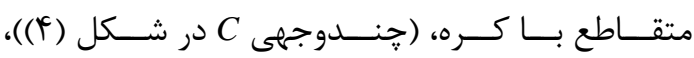
وجوه خارج از كره حذف مىشوند.
جندضلعى استفاده شده است. براى محاسبه مؤلفههـاى بردار نرمال $\vec{N}$ در جندضلعىهاى غير محدب، مى تـوان

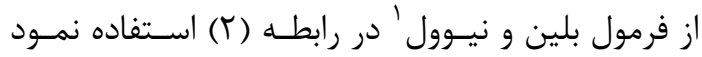
(r) رابطه

$\left\{\begin{array}{l}N_{x}=\sum_{i=1}^{n}\left(y_{i}-y_{\text {next }(i)}\right)\left(z_{i}+z_{\text {next }(i)}\right) \\ N_{y}=\sum_{i=1}^{n}\left(z_{i}-z_{\text {next }(i)}\right)\left(x_{i}+x_{\text {next }(i)}\right) \\ N_{z}=\sum_{i=1}^{n}\left(x_{i}-x_{\text {next }(i)}\right)\left(y_{i}+y_{\text {next }(i)}\right)\end{array}\right.$

كه در اين رابطه، n نشاندهنده تعداد نقاط جندضـلعى، موقعيت نقطهى $i\left(x_{i}, y_{i}, z_{i}\right)$ بعد از i است. اين روش قادر به تخمــين بهتــرين بـردار

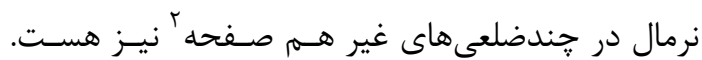

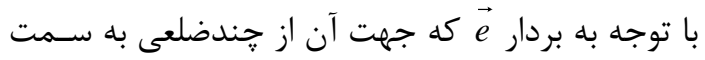

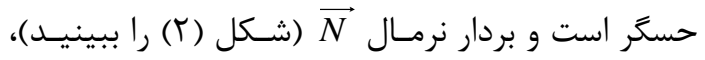

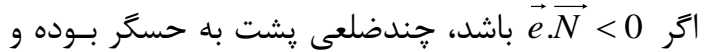

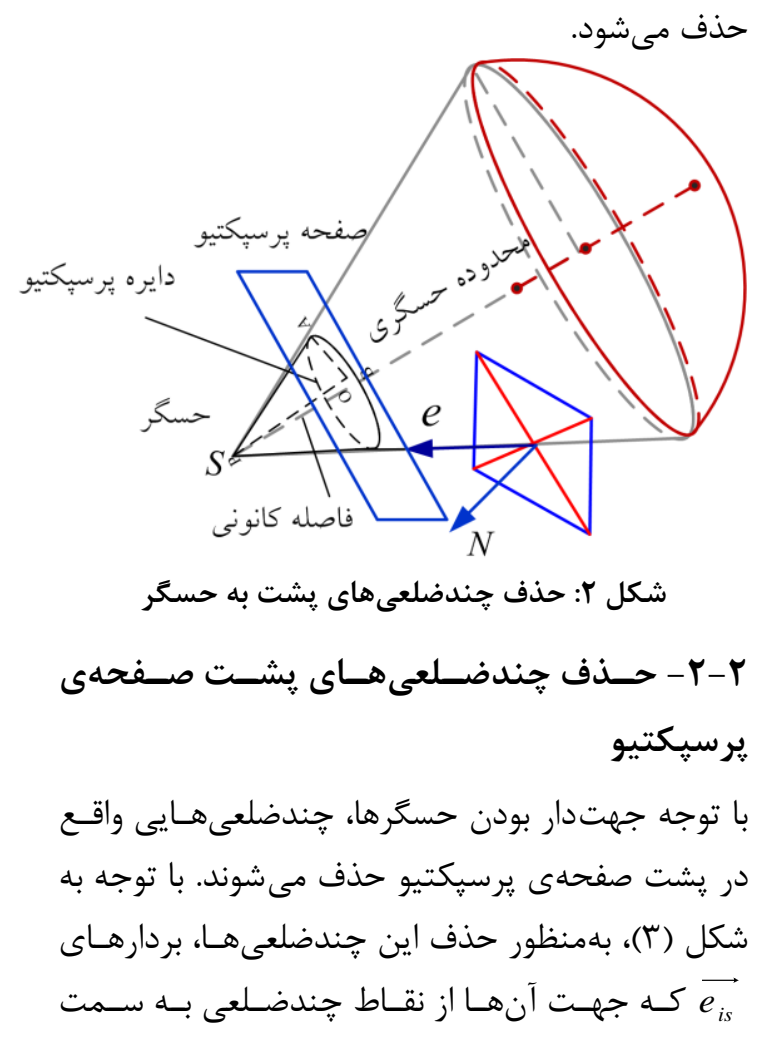

${ }^{1}$ Blinn \& Newell

${ }^{2}$ Non planar 

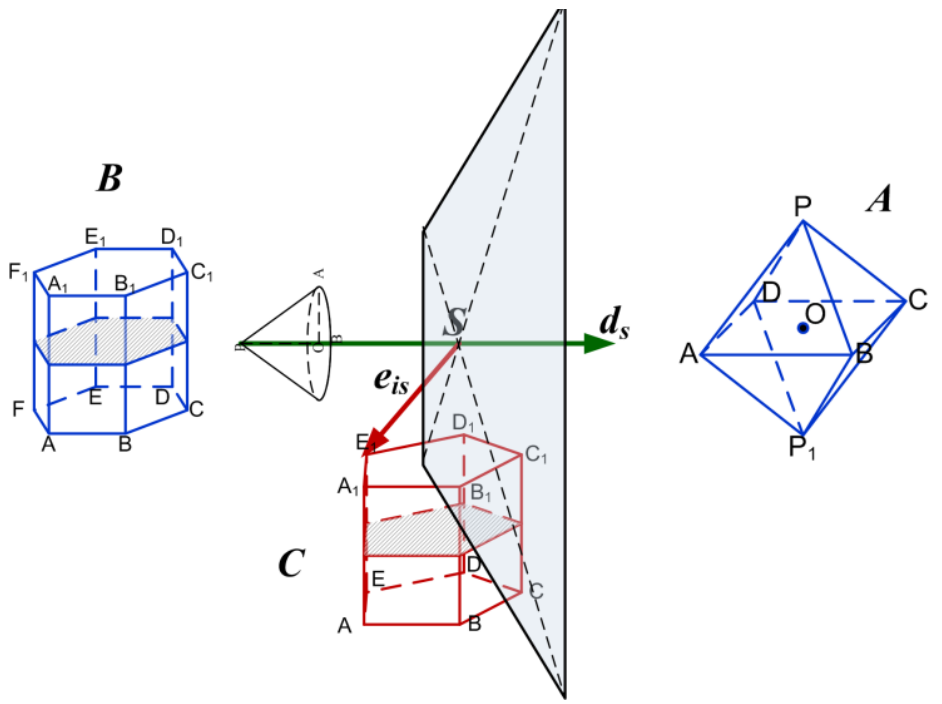

شكل ץّ: حذف وجوه B كه در يشت صفحهى يرسيكتيو قرار كرفته است. بخشى از وجوه C كه در يشت صفحدى يرسيكتيو قرار كرفته بايد حذف شوند.

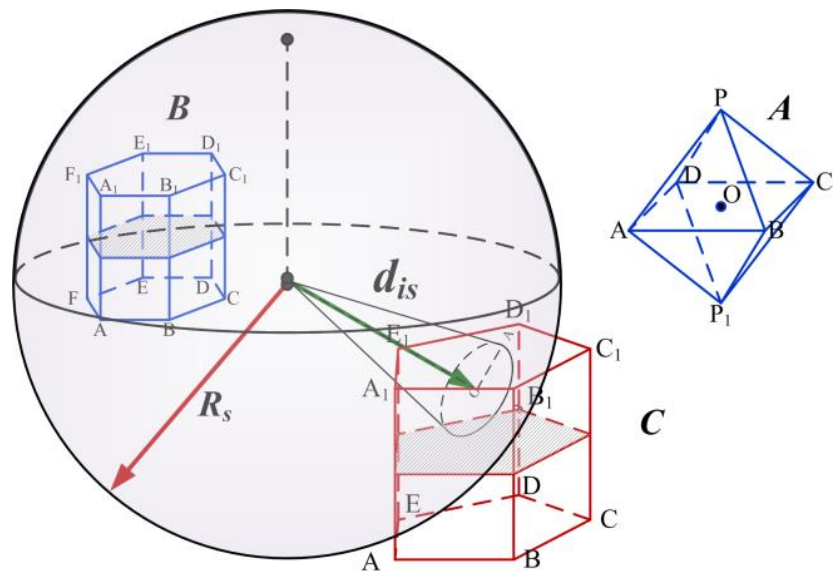

شكل F: حذف وجوهى از A كه در خارج از محدودهى فاصله عملكرد حسكر قرار دارد. بخشى از وجوه C كه در خارج از

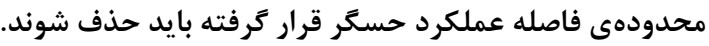

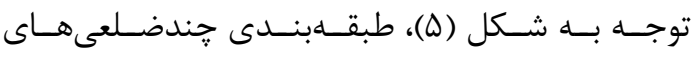
تصوير شده بدين صورت است:

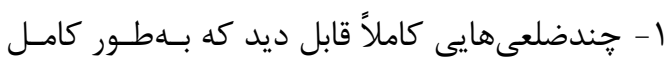

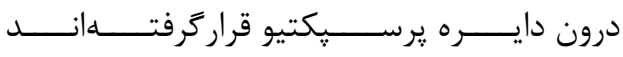
(جندضلعى هاى A و B (B).

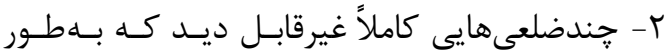
كامل در خارج از دايره يرسيكتيو قرار گرفته و در محدودهى زاويه عملكرد حسگر واقع نشدهاند.

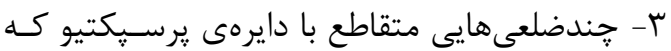

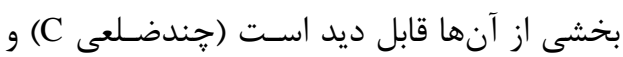

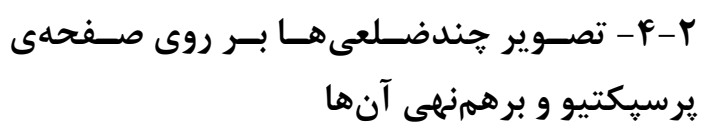

در اين مرحله، به حذف جندضلعىهايى كه توسط ديگر

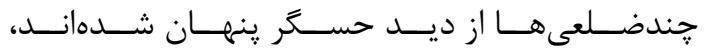
يرداخته مىشود. بر اين اساس، جندضـلعىهـاى مــورد

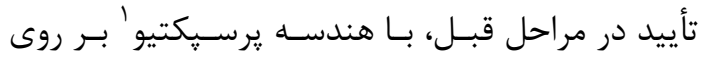

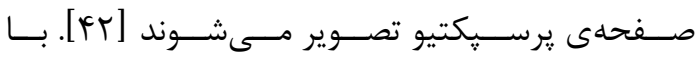

${ }^{1}$ Perspective geometry 


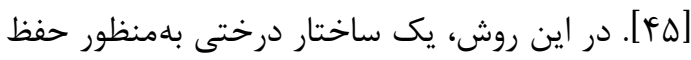
اطلاعات نسبى عمق بين جندضلعىها ايجاد مىشود.

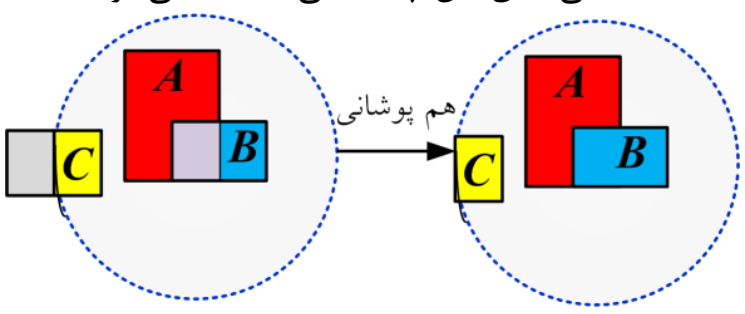

شكل 9: برهمنهى جندضلعى ها با دايره پرسيكتيو و با يكديكر

در اين مرحله، يس از تعيين جندضلعىهاى قابلرؤيــت

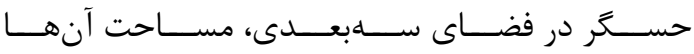

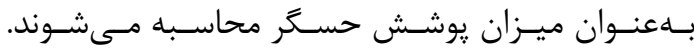

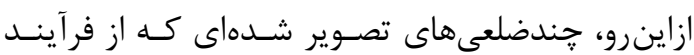

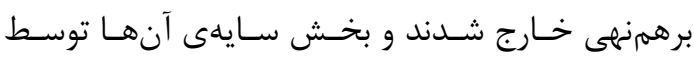
جندضلعىهاى ديخر حذف شـد، در انتهـا بـه صـفحهى קندضلعى سهبعدى خود انتقال مسىيابنـد (بخـش (ب)

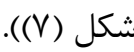
اين קندضلعىها تنها جندضلعىهايى هستند كه توسط حسكر يوشش داده مىشوند. بهمنظور محاسبه مساحت

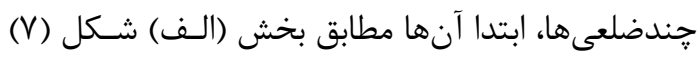

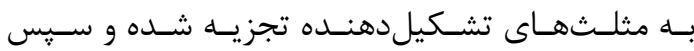

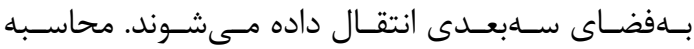

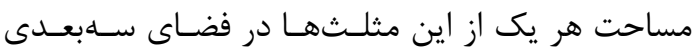
بر اساس رابطه (ץ) قابل محاسبه است: $S_{\Delta}=0.5 \times\left|\operatorname{cross}\left(\overrightarrow{v_{2}}-\overrightarrow{v_{1}}, \overrightarrow{v_{3}}-\overrightarrow{v_{2}}\right)\right|$

رابطه (ए) كه اين رابطه بر اسـاس ضـرب خـارجى بــين دو بـردار

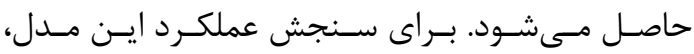

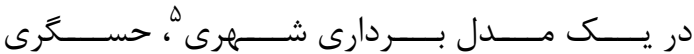

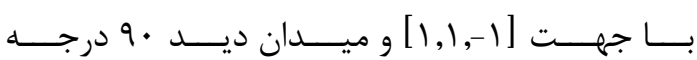

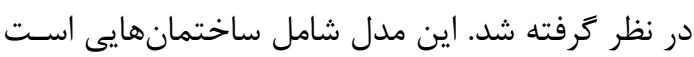

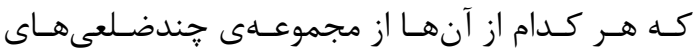

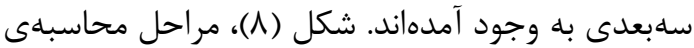
يوشش منطقه تحت يوشش حسكر را براى ايـن نمونسه

\footnotetext{
${ }^{5}$ City GML
}

نواحى قابل ديد اين جندضلعىها، به كمك تقاطع

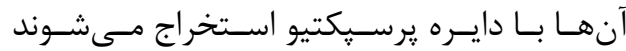

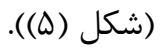

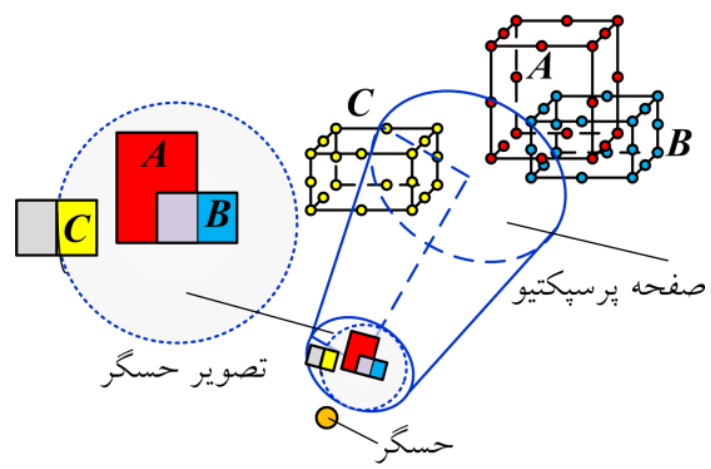
شكل ه: طبقهبندى جندضلعىهاى تصويرشده بر روى صفحهى يرسيكتيو بر اساس موقعيت آنها نسبت به دايره برسيكتيو براس موفيت

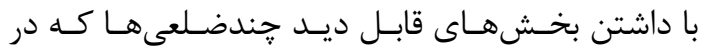

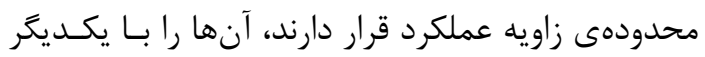

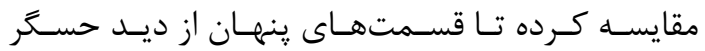

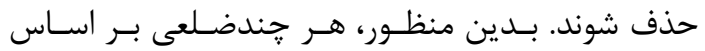

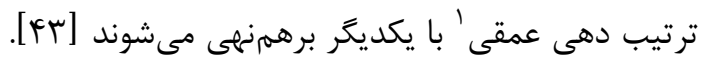

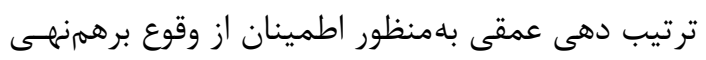

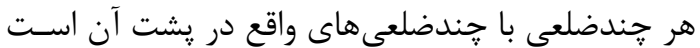

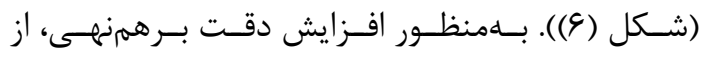

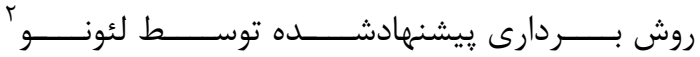

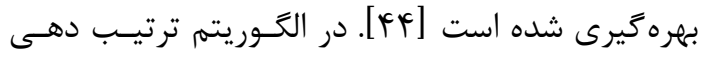

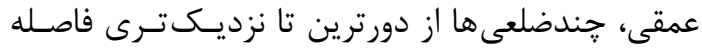

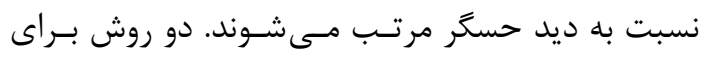

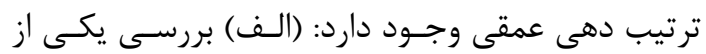

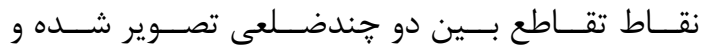

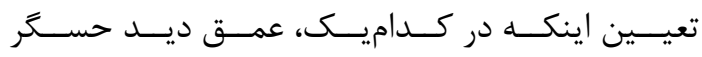

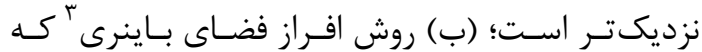

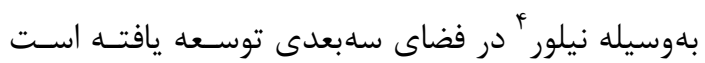

${ }^{1}$ Depth sorting

${ }^{2}$ Leonov

${ }^{3}$ Binary space partitioning

${ }^{4}$ Naylor 


\section{نشريه علمى يُروهشى - مهندسى فناورى اطلاعات مكانى}

I سال ششم • شماره نخست • بهار IVV

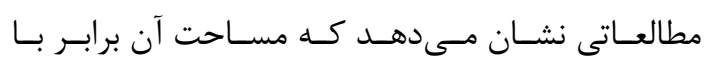
IIVTRq

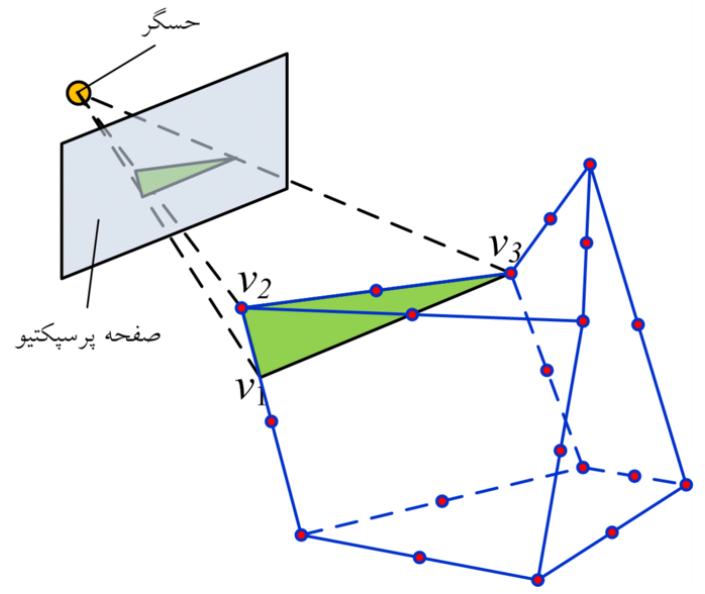

(ب)

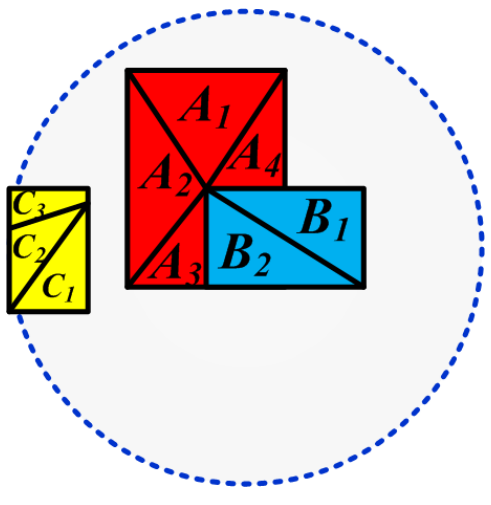

(الف)

شكل V: (الف) تبديل جندضلعى ها به مثلثهاى تشكيل دهندهى آن؛ (ب) انتقال مثلثها
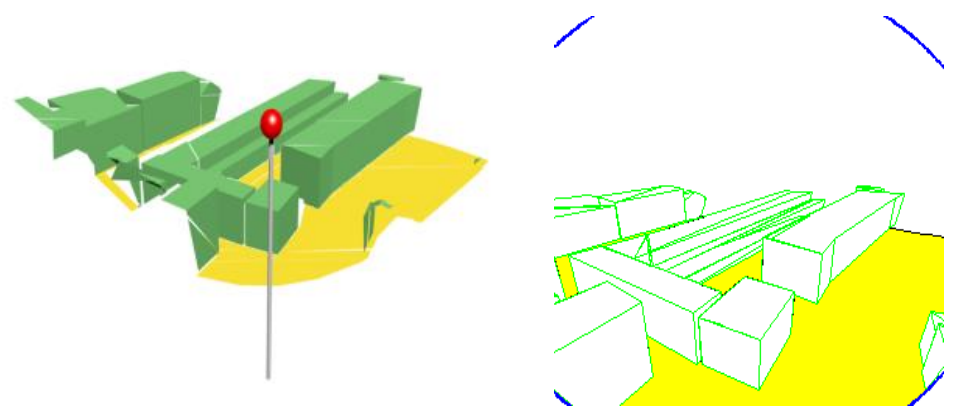

(ج)

(ب)

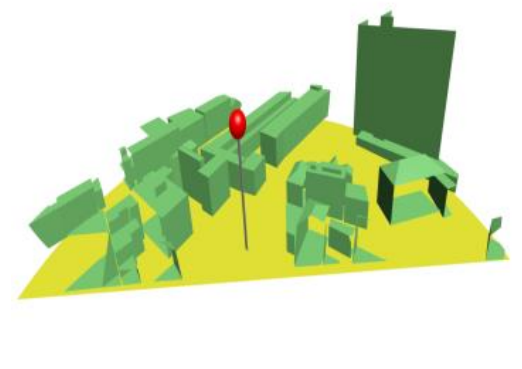

(الف)

شكل ^: (الف) جندضلعى هايى كه روبهرو به حسكر هستند و در محدودهى فاصلهى عملكرد آن قراركرفتهاند؛

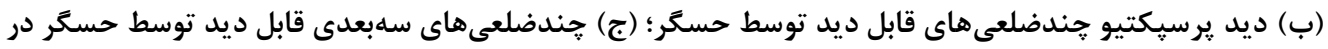
فضاى سهبعدى

MCSDP با رويكردى نـوين و بـا لحـاظ نمـودن قيـود

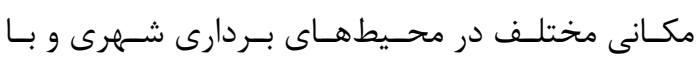

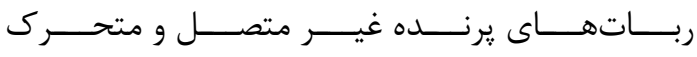
يرداخته شده است. هر ربات يرنده مجهز به يك حسكر

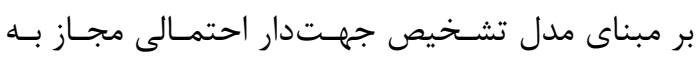
حركت در راستاهاى مختلف براى دستيابى به بيشترين

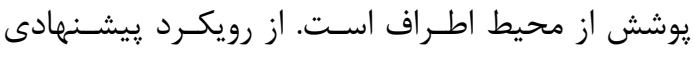

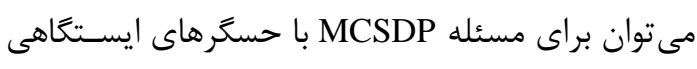

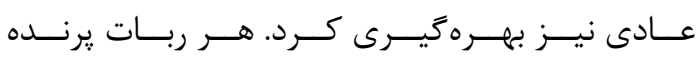

اين رويكرد قادر است مساحت جندضلعىهـاى كنـارى

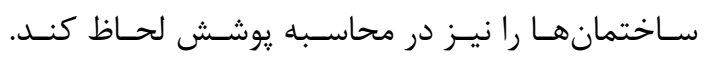

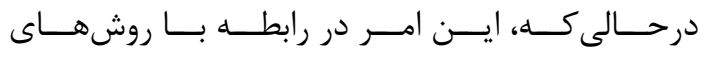
محاسبه يوشش در مدل رسترى محيط انجام نمى ديود.

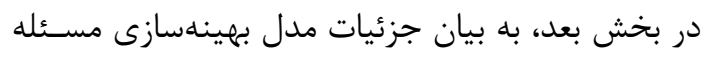

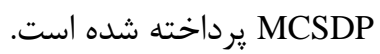

MCSDP باختار مسئله

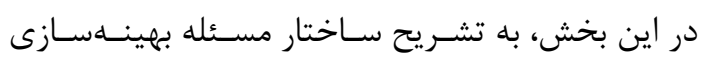


حركت ربات يرنده، در مسئله پيش رو با قيـود ديخــى

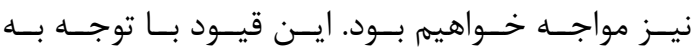

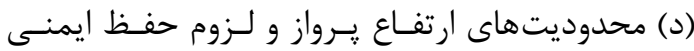

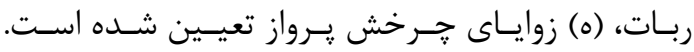
بر اساس قيد شرط ايمنى در معادلـه (9)، بايسـ كمينــهـ

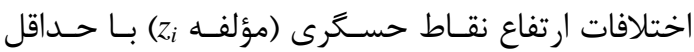

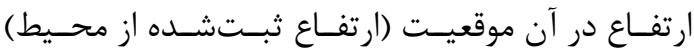
بيش از ارتفاع ايمن ان مون

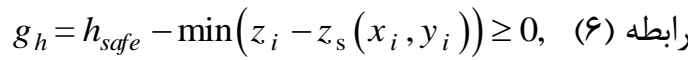
كه در اين رابطه

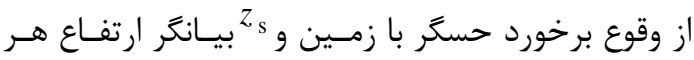
موقعيـت در روى مــدل رقمـى زمــين اسـت كـــه در

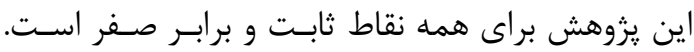

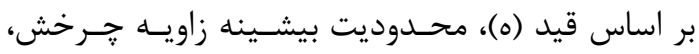

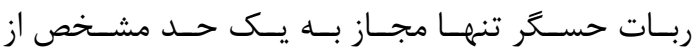
تغيير جهت در هر نقطه است. بر مبناى قيد رابطه (V)، زاويه بيشينه جرخش بايد در محدوده زير باشد:

(V) رابطه

$$
g_{\varphi}=\max \left(\varphi_{i}-\varphi_{i}^{\max }\right) \geq 0, i=0,1, \ldots, n-1
$$

كــــــه در رابطـــــــه (V)، زاويه جرخش افقى در هر موقعيت است كه بـر مبنــاى رابطه (N) به فراخور بيشـينه اضـافه بـار يهلـويى

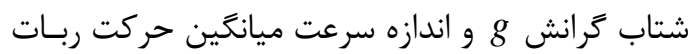

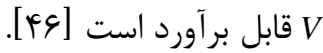

رابطه (^)

$$
\varphi_{k}^{\max }=\frac{n_{\max } g}{V}\left[\left(x_{i+1}-x_{i}\right)^{2}+\left(y_{i+1}-y_{i}\right)^{2}\right]^{1 / 2}
$$

قيد (الف) به اين صورت اعمال مىشود: اخـر مختصـات

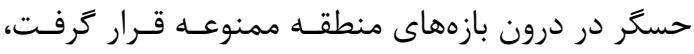

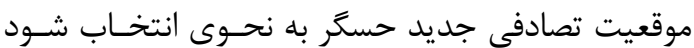
كه در درون منطقه ممنوعه قـرار نخيـرد. در قيـد (ب)، حسگرها بايد در يك منطقه از ييش تعيينشده جايـابى

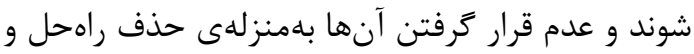
ايجاد راهحلى است كه حسكرها بهطور مجــد در درون

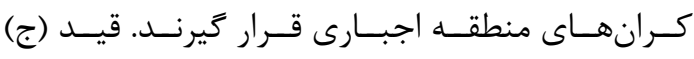

اطلاعات يوششى را باصورت مستقيم به واحد يردازنـده

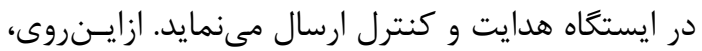
نيازى به تبادل اطلاعات با ديخر حسگرها و لحـاظ قيـد حفظ ارتباط بين حسگرها نيست و هر حسگر بهصـورت

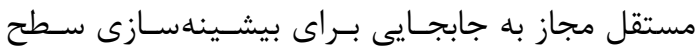
تحت يوشش خود از عوارض است. همجنــين فـرض بـر

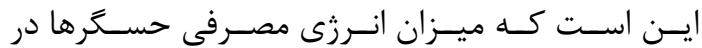

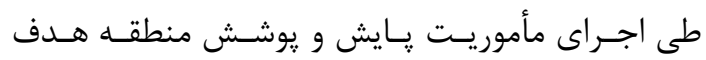
كافى باشد. تابع احتمال جهت حسگر ربـات زيرنـده نيـز بر اساس عملكرد واقع گرايانهاى كه در رديابى احتمـالى حسخرها در محيطهاى سلبعدى رخ مىدهد، بـا توجـهـ به رابطه (f) بيان مى شود: $P_{\alpha}=0.5 \times \omega \times[\cos (\alpha-\theta)+1] \quad$ (I)

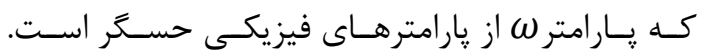

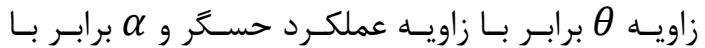
زاويهاى است كه بردار حسگر به هدف با بردار جهت آن

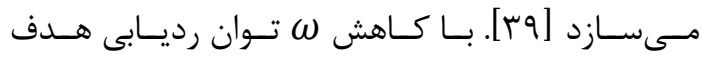
تقويت مىشود. تابع هـدف مسـئله MCSDP مطـرح در ايـن يـزروهش، بلهورت بيشينهسازى مجموع مسـاحت تحـت يوشـش مجموعه حسگرها با توجه به رويكرد ارائهشده در بخش

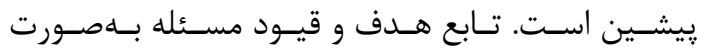
رابطه (ه) بيان مى گر دند: رابطه (ه)

Minimize $\sum_{t=1}^{m} S_{t}-\sum_{i=1}^{n} S_{\Delta, i}$

subject to $\mathrm{g}_{h}, g_{\varphi} \geq 0$,

$$
H_{A Z}, H_{P Z}=0
$$

كه n تعداد كل مثلثهاى قابل تشخيص در بخش قبـل،

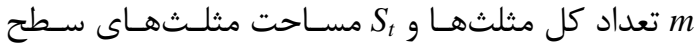
اسـت. در رابطــهـهـــا قيـدهاى لحـاظ شــده در مســـله

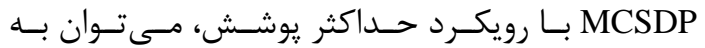
(الــف) قيـد عـدم اسـتقرار در منطقــه ممنوعــه،

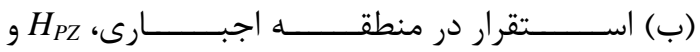

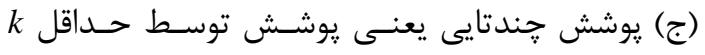

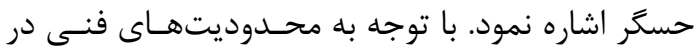


هر رود تخصيص مىيابد. نحوه جارى شـدن شـريانهـا

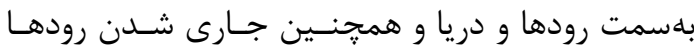
بهسمت درياها موجب حركت پِاسخهـاى نـامزد مسـئله

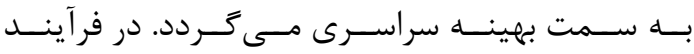

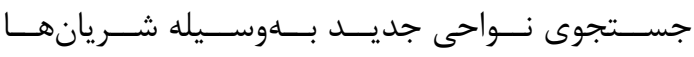

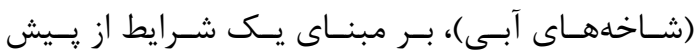

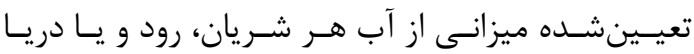
تبخير شده (حـذف تـدريجى ياسـخهــاى ضـعيف) و از

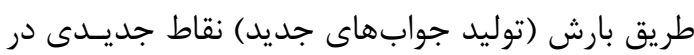

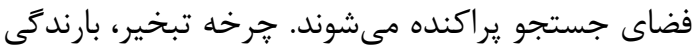

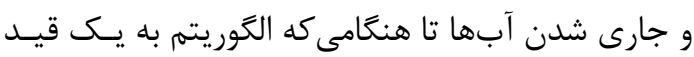

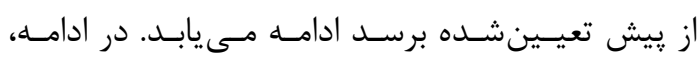

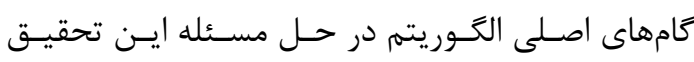
بيان مى

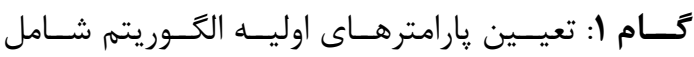

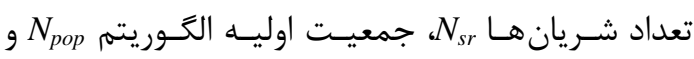
تعيين حداكثر تكرارها و يـارامتر دقت تشكيل جمعيت اوليه ياسخهاى الگوريته. جمعيت اوليه شامل مجموعه اى از

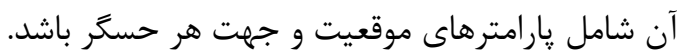

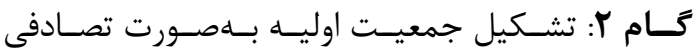

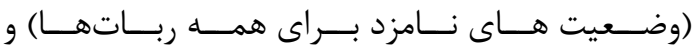
تشكيل شريانها، رودها و درياى اوليه بر اساس كدينَ

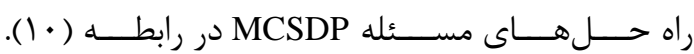

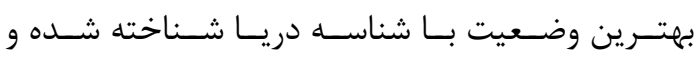

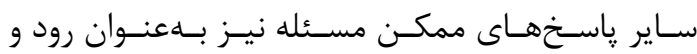
شريانها در رابطه ( • إو ||(1) متمايز مىشوند.
باعـث افـزايش قطعيـت رديـابى منطقـهـ مـىشـــود و

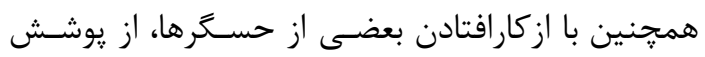

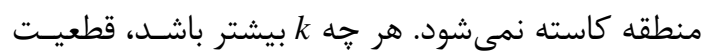
يوشش منطقه بالاتر مىرود. براى رسيدن به اين هدف،

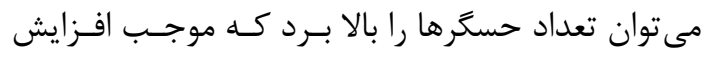

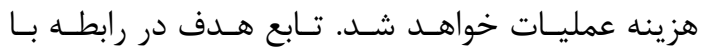
اين قيد، مطابق رابطه (9)، عبارت است از بيشينهسازى

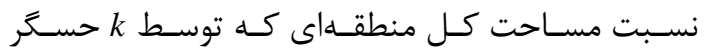
يوشش مى يابنــد بـه حـداكثر مســاحتى كـه حســرها

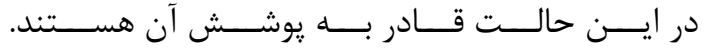
براى تبديل مسئله به كمينه سازى نسبت نظيـر از كـل

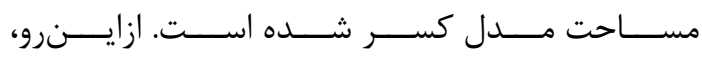
راهحلهاى الگوريتمهاى بهينهسازى سراسرى بر اساس اين مقدار بهروز مىشوند. ) رابطه (9)

Minimize $\sum_{t=1}^{m} S_{t}-\sum_{i=1}^{k} S_{\Delta, i} / \sum_{i=1}^{n} S_{\Delta, i}$ subject to $\mathrm{g}_{h}, g_{\varphi} \geq 0$,

$$
H_{A Z}, H_{P Z}=0
$$

F - الكَوريتم بهينهسازى جرخه آب در حل مسئله MCSDP الكوريتم بهينهسازى جرخه آب يك روش بهينـهسـازى

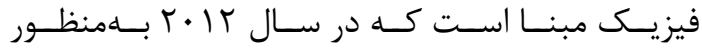
حل مسائل بهينهســازى مقيـد مطـرح شـده اسـت و از

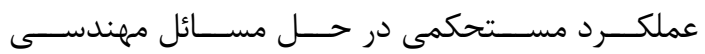

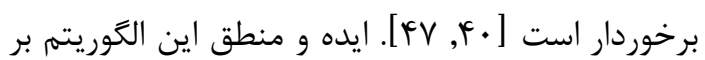
مبناى نحوه توزيع شريانهاى ' آبسى در سـطح زمــين و و

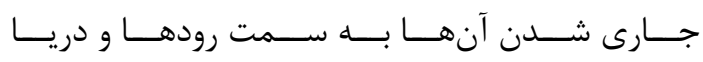

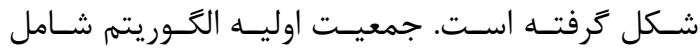
مجموعــهاى تصـادفى از شـريانهــاى آبـى، رودهــا و دريا است. در اين الخوريتم بهترين پاسخ مسئله (بهينـهـ

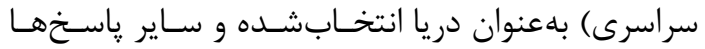

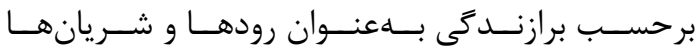

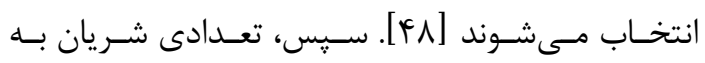

\footnotetext{
${ }^{1}$ Stream
} 
رابطه (•)

$$
\begin{aligned}
& {\left[\begin{array}{c}
X_{\text {Sea }} \\
X_{\text {River }_{1}} \\
\vdots \\
X_{\text {Stream }_{N_{s+1}}} \\
\vdots \\
X_{\text {Stream }_{N_{\text {pop }}}}
\end{array}\right]==\left[\begin{array}{ccccccccccccccccc}
X_{1}^{1} & \ldots & X_{N}^{1} & Y_{1}^{1} & \ldots & Y_{N}^{1} & H_{1}^{1} & \ldots & H_{N}^{1} & I_{1}^{1} J_{1}^{1} & K_{1}^{1} & \ldots & I_{N}^{1} & J_{N}^{1} & K_{N}^{1} \\
X_{1}^{2} & \ldots & X_{N}^{2} & Y_{1}{ }^{2} & \ldots & Y_{N}^{2} & H_{1}^{2} & \ldots & H_{N}^{2} & I_{1}^{2} & J_{1}^{2} & K_{1}^{2} & \ldots & I_{N}^{2} & J_{N}^{2} & K_{N}^{2} \\
\vdots & \vdots & \vdots & \vdots & \vdots & \vdots & \vdots & \vdots & \vdots & \vdots & \vdots & \vdots & \vdots & \vdots & \vdots & \vdots \\
X_{1}^{N} & \ldots & X_{N}^{N_{\text {pop }}} & Y_{1}^{N} & \ldots Y_{N}^{N_{\text {pop }}} & H_{1}^{N} & \ldots & H_{N}^{N_{\text {pop }}} & I_{1}^{N} J_{1}^{N} & K_{1}^{N} & \ldots & I_{N}^{N_{p o p}} & J_{N}^{N_{\text {pop }}} & K_{N}^{N_{\text {pop }}}
\end{array}\right]}
\end{aligned}
$$

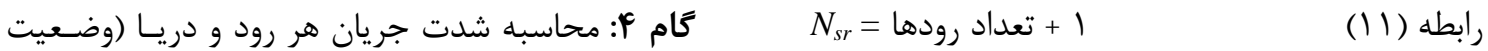

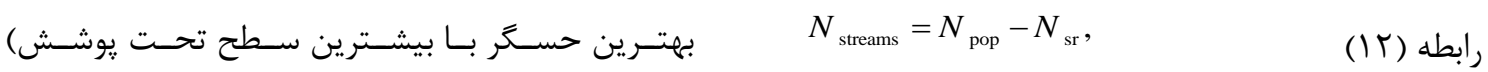

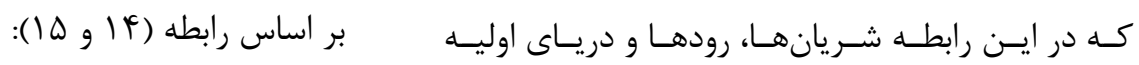

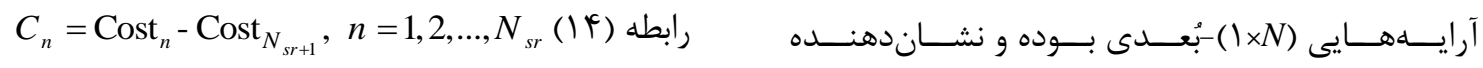

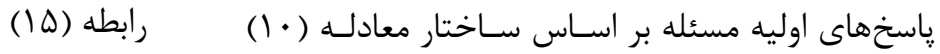

$$
\begin{aligned}
& N S_{n}=\operatorname{round}\left\{\left|C_{n} / \sum_{i=1}^{N_{s r}} C_{n}\right| \times N_{\text {streams }}\right\}, n=1,2, \ldots, N_{s r} \\
& \text { كه در اين رابطه NS N مكداد جريانات را نشان مى مدهد. } \\
& \text { كام ه: در اين مرحله، شريانها بر اسـاس رابطـهـ (19 و و رابطه }
\end{aligned}
$$

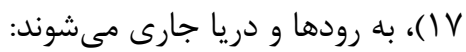

$$
\begin{aligned}
& \text { هستند. }
\end{aligned}
$$

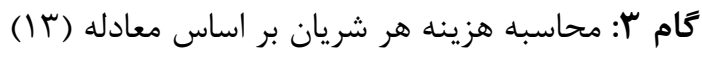

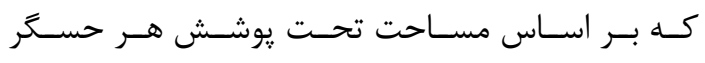

$$
\begin{aligned}
& \text { محاسبه مىشود: }
\end{aligned}
$$

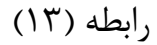

$$
\begin{aligned}
& C_{i}=\operatorname{Cost}_{i}=\sum_{t=1}^{m} S_{t}-\sum_{i=1}^{k} S_{\Delta, i} / \sum_{i=1}^{n} S_{\Delta, i} \\
& =f\left(x_{1}^{i}, x_{2}^{i}, \ldots, x_{N}^{i}\right), i=1,2,3, \ldots, N_{p o p},
\end{aligned}
$$

$$
\begin{array}{ll}
X_{\text {Stream }}(t+1)=X_{\text {Stream }}(t)+r_{1} \otimes K \otimes\left(X_{\text {River }}(t)-X_{\text {Stream }}(t)\right), & \text { رابطه (1) رابطه (IV) }
\end{array}
$$

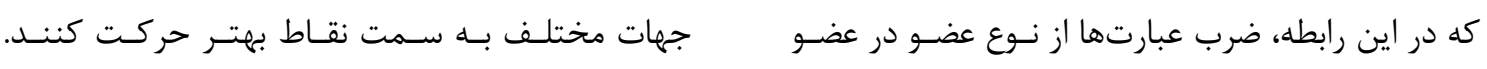$$
\text { است، }
$$

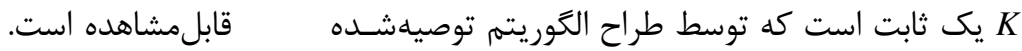

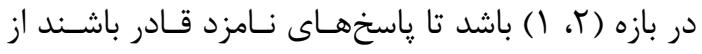

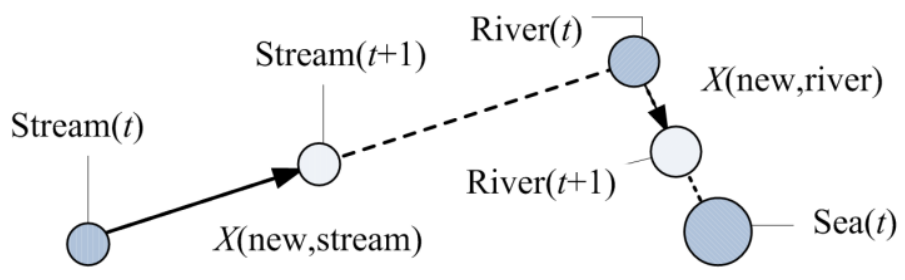

شكل 9: نحوه جارى شدن جريانات به رودها و رودها به دريا

كام 9: رودهـا بـر اسـاس رابطـهـ (1) بــه دريـا جـارى مىشوند:

$X_{\text {River }}(t+1)=X_{\text {River }}(t)+r_{3} \otimes K \otimes\left(X_{\text {Sea }}(t)-X_{\text {River }}(t)\right)$,

رابطه (1)

كام V: جايكزينى رود بـا شـريانى كـه هزينـه كمتـرى (يوشش بيشترى) داشته باشد. 


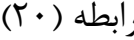

$X_{\text {Stream }}^{\text {new }}(t+1)=X_{\text {sea }}+\mu^{0.5} \otimes \operatorname{randn}\left(1, N_{\text {var }}\right)$,

در رابطـــه بــالا ضـريب ر مشــابه مفهـــوم واريــانس،

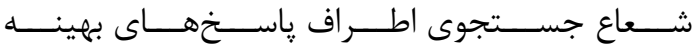

(وضعيت حسكرهاى برتر) ) را كنترل مى كند.

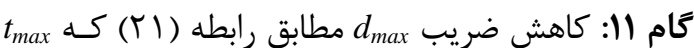
نشاندهنده حداكثر تكر ارها است: $d_{\text {max }}(t+1)=d_{\text {max }}(t)-d_{\text {max }}(t) / t_{\text {max }}$,

(YI) (Y)

كام זا: بررسى شرايط توقف الكوريته. در صورت لـزوم تكرارهاى بيشتر الكوريتهم به كام ه بازمى كردد.

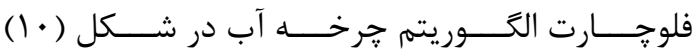
نمايش داده شده است. براى بهكاركيرى ايـن الخـوريته

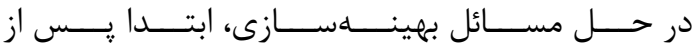

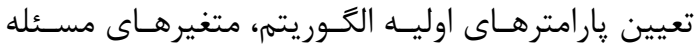

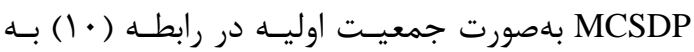

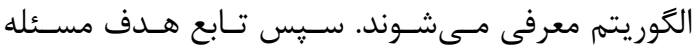

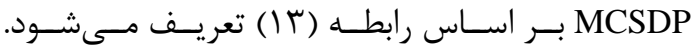

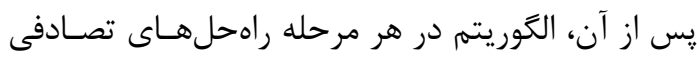

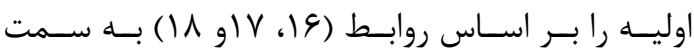
ياسخهاى بهتـر (وضـعيت هـاى ممكـن حســرهاى بـا

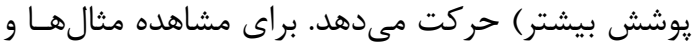

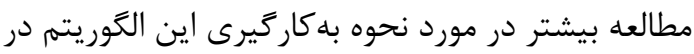
حل مسائل بهينهسازى به مرجع [••[F] مراجعه شود.
كام 1: جايكزينى رود بـا دريـايى كـه هزينــه بيشـترى (يوشش كمترى) داشته باشد.

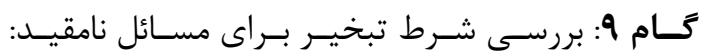
درصــورتىكسه ه

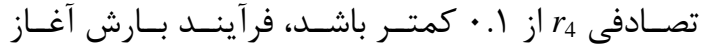
مىشود. در اين رابطه،

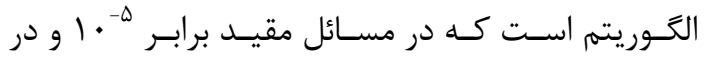

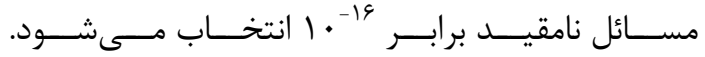

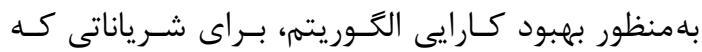

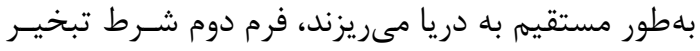

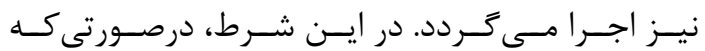
شاش $\left|X_{\text {Sea }}-X_{\text {stram }}^{i}\right|<d_{\text {max }}$

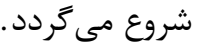
كام •ا: پِ از بررسى شرط تبخيـر، بـارش بـهــورت

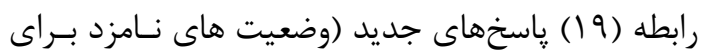
حسگرها) را در محيطهاى نامقيد توليد مى كند: $X_{\text {Stream }}^{\text {new }}(t+1)=L b+r_{5} \otimes(U b-L b), \quad$ رابطه (19 (19)

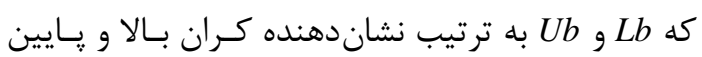

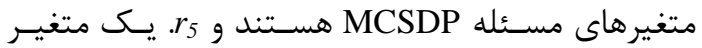
تصادفى است. براى مسائل مقيد، معادله بارش بلهصورت رابطه (·r) تغيير مى كند:

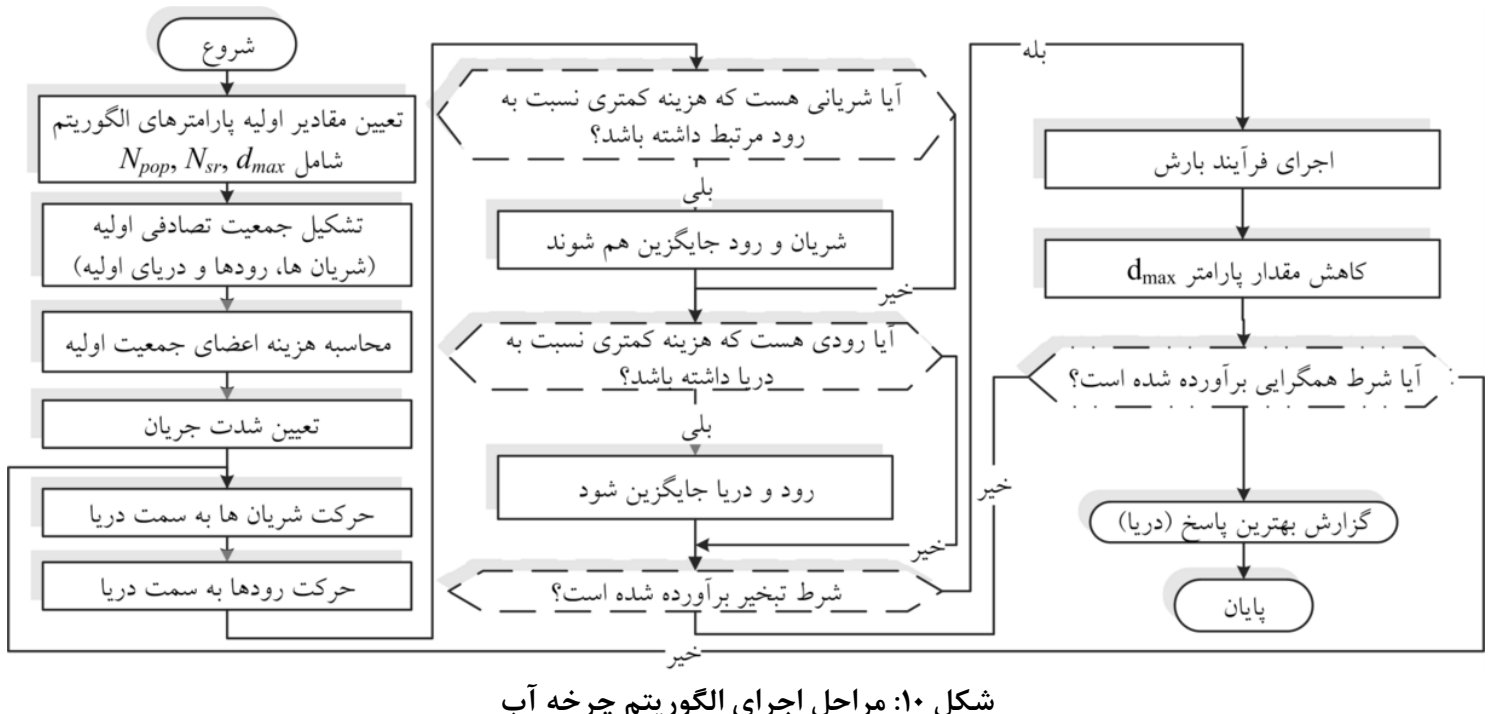


و بخش عمده عملكرد الخَـوريتهم نيـز بـهـ ايـن عملكَرهـا وابسته است.

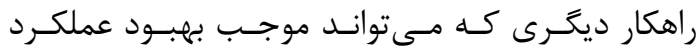

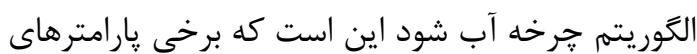

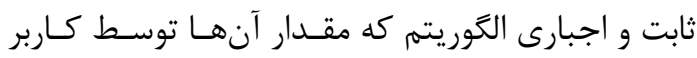
تغيير نمى كند (نظير پارامتر K)، بهصـورت دينـاميكى و و بر مبناى يك معادله نزولى در مسير پِيشرفت الخــوريته

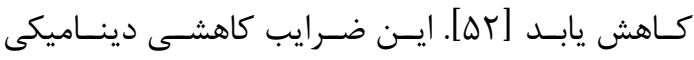

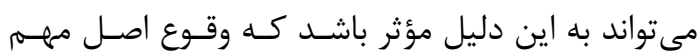

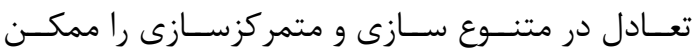

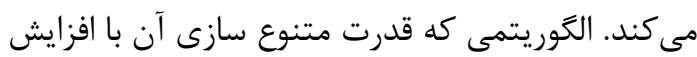

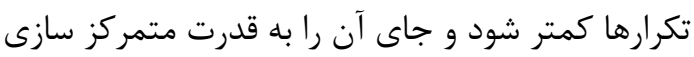

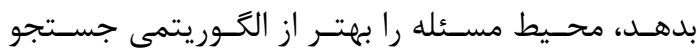

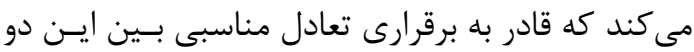

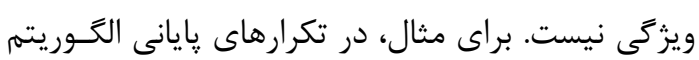

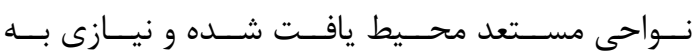
يراكندهسازى نقـاط نيست، آنجـهـ روش در تكرارهـاى

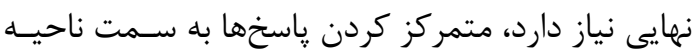

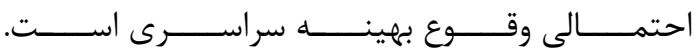

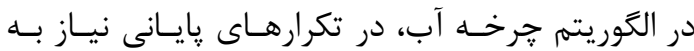

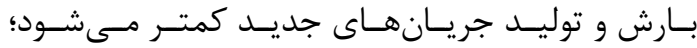

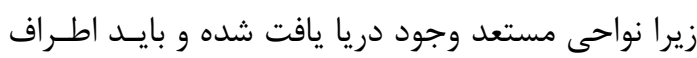
اين نواحى با دقت (تمركز) بيشترى جستجو گردد. بر اين اساس، در نسخه بِيشنهادى اين مقاله، شريانهـا

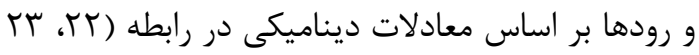
و و (TF به سمت دريا حركت مى كنند:

\section{F-1- الكوريته وييشنهادى بهبوديافته جرخه آب} در الخَوريتهم اسـتاندارد جرخــهـ آب، تنهــا يـك راهكـار

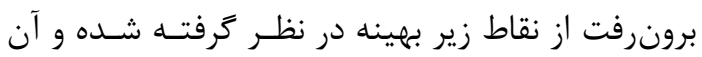
اين است كه براى شريانهـايى كـهـ مسـتقيماً بـهـ دريـا

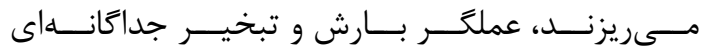
در نظر كرفته مىشود؛ اما اين ايده نمىتواند به خوبى از

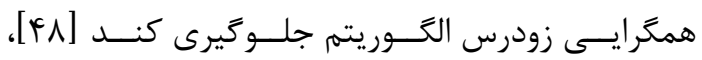
جنانجه در برخى مسائل و در ابتداى جستجو الحَــوريتم

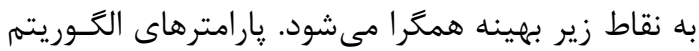

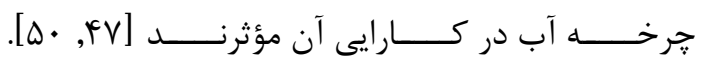

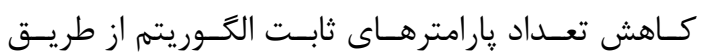
تعيين خودكار پيارامترها (بهصورت ديناميكى) مىتوانـــ عملكرد روش را متناسب بـا ميـزان بيشـرفت الخَــوريته

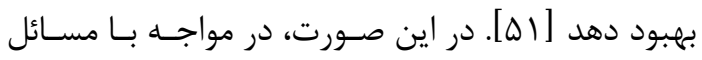

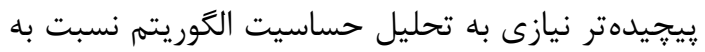

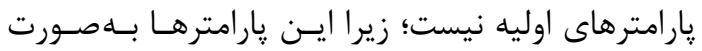
ديناميكى در طول تكرارهاى الكَوريتم تغيير مسى كنينـد.

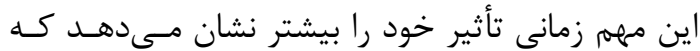

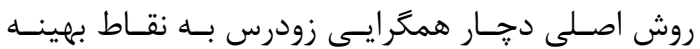

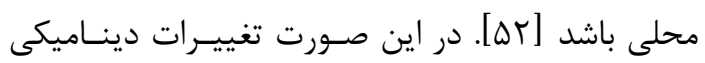

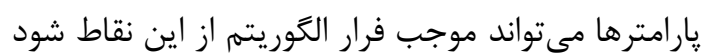

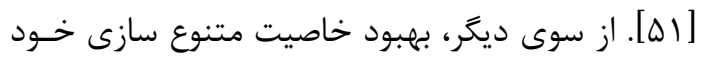
وابسته به سازوكار عملكَرهاى جستجوى الكوريتم است.

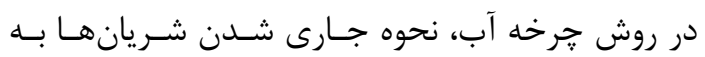

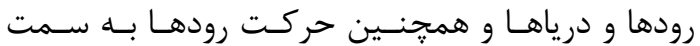

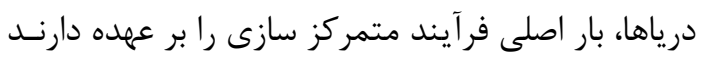

$X_{\text {Stream }}(t+1)=X_{\text {Stream }}(t)+K(t) \otimes\left(X_{\text {Sea }}(t)-X_{\text {Stream }}(t)\right)$,

$X_{\text {Stream }}(t+1)=X_{\text {Stream }}(t)+K(t) \otimes\left(X_{\text {River }}(t)-X_{\text {Stream }}(t)\right)$,

رابطه (Tr)

$$
X_{\text {River }}(t+1)=X_{\text {River }}(t)+K(t) \otimes\left(X_{\text {Sea }}(t)-X_{\text {River }}(t)\right),
$$

رابطه (TF)

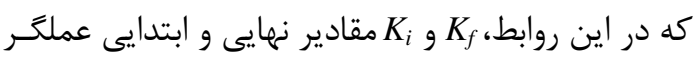

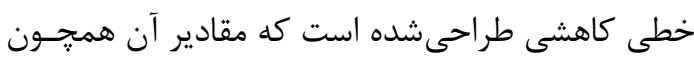

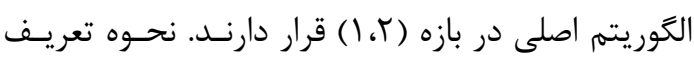

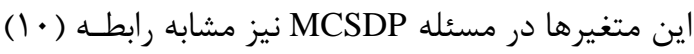

كه در روابط بالا (T) تابعى نزولى و آشـوبى اسـت كـهـ بر اساس رابطه (TD) تعيين مىشود: رابطه (T)

$K(t)=\left(K_{i}+\left(K_{f}-K_{i}\right) \times\left(t / t_{\max }\right)\right) \times U F(t)$, 


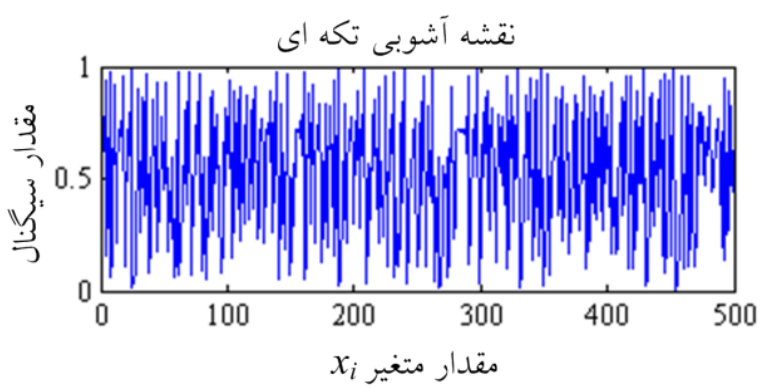

شكل ||: رفتار سيخنال تكهاى

نحوه اجراى شبه كد الكوريتم پِيشنهادى در شكل (T) قابلمشاهده است.

ه- ارزيابى و تحليل نتايج

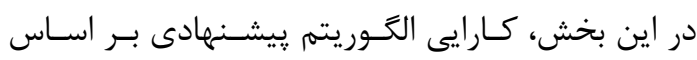

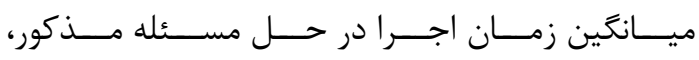

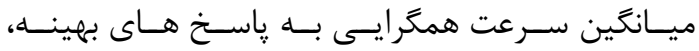

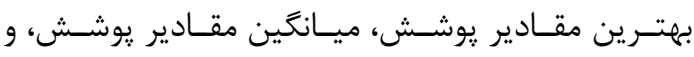

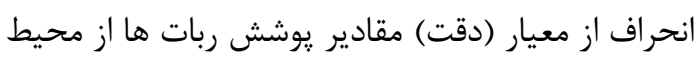
با الكوريتههـاى جمعيـت مبنـاى زنتيـك GA GWO

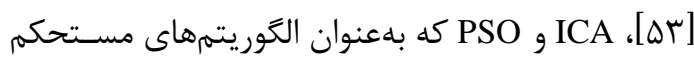

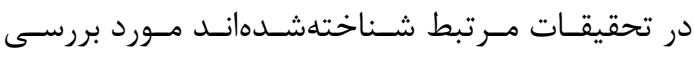

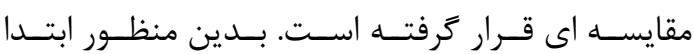
يار امترهاى اوليه مســـله و الخــوريتمهــا تعيـين شـده و

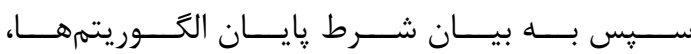

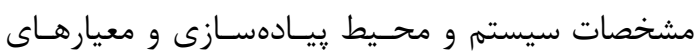

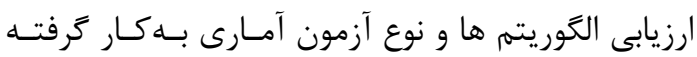

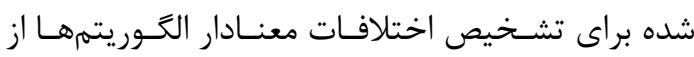

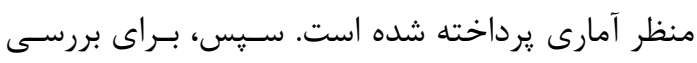
تأثير قيود مكانى مختلف بر كارايى الكوريتمها و تحليل

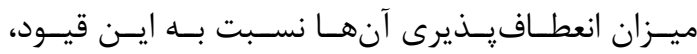

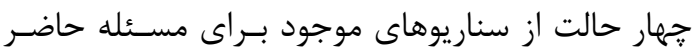
در نظر زرفته شده است.
و مراحل مطرح در بخش قبل بوده است. همزپنين

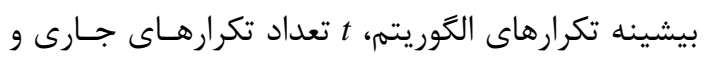
بيانگر تابع مولد الخوهاى آشـوبى در هــر تكــرار

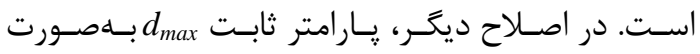
آشوبى و در هر تكرار الكوريتم تعيين مىشود. ايـن امـر باعث كاهش يارامترهاى ثابت اوليه و تغييـر مقـادير آن

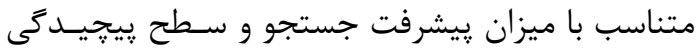

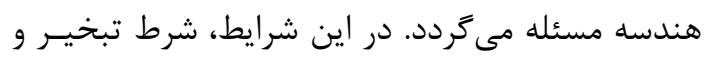

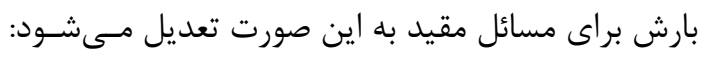

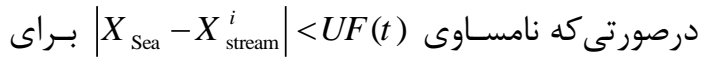
i=1, برقرار باشد، آنگاه فرآيند ديناميكى

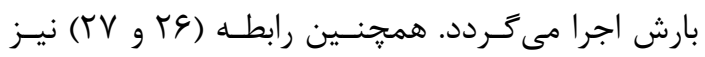
بهصورت ديناميكى تغيير خواهد كرد. $X_{\text {Stream }}^{\text {new }}=X_{\text {sea }}+[\mu(t)]^{0.5} \otimes U F(t)$,

رابطه (4) (19)

$(Y V)$ رابط $\mu(t)=\left(\mu_{i}+\left(\mu_{f}-\mu_{i}\right) \times\left(t / t_{\max }\right)\right)$, كـهـ در ايسـن رابطـه،

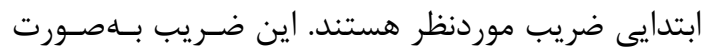

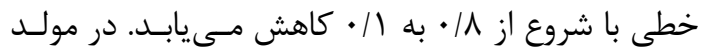
UF

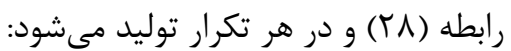

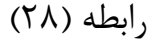

$x_{k+1}= \begin{cases}\frac{x_{k}}{P} & 0 \leq x_{k}<P \\ \frac{x_{k}-P}{0.5-P} & P \leq x_{k}<0.5 \\ \frac{1-P-x_{k}}{0.5-P} & 0.5 \leq x_{k}<1-P \\ \frac{1-x_{k}}{P} & 1-P \leq x_{k}<1\end{cases}$

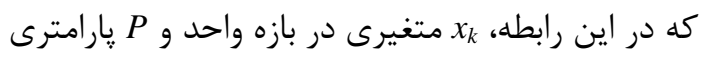

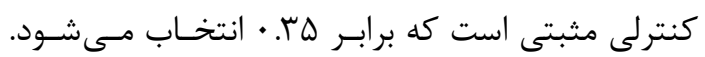

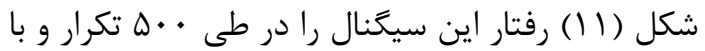
شروع از مقدار اوليه V. • نشان مى لـدهد.

${ }^{1}$ Piecewise map 


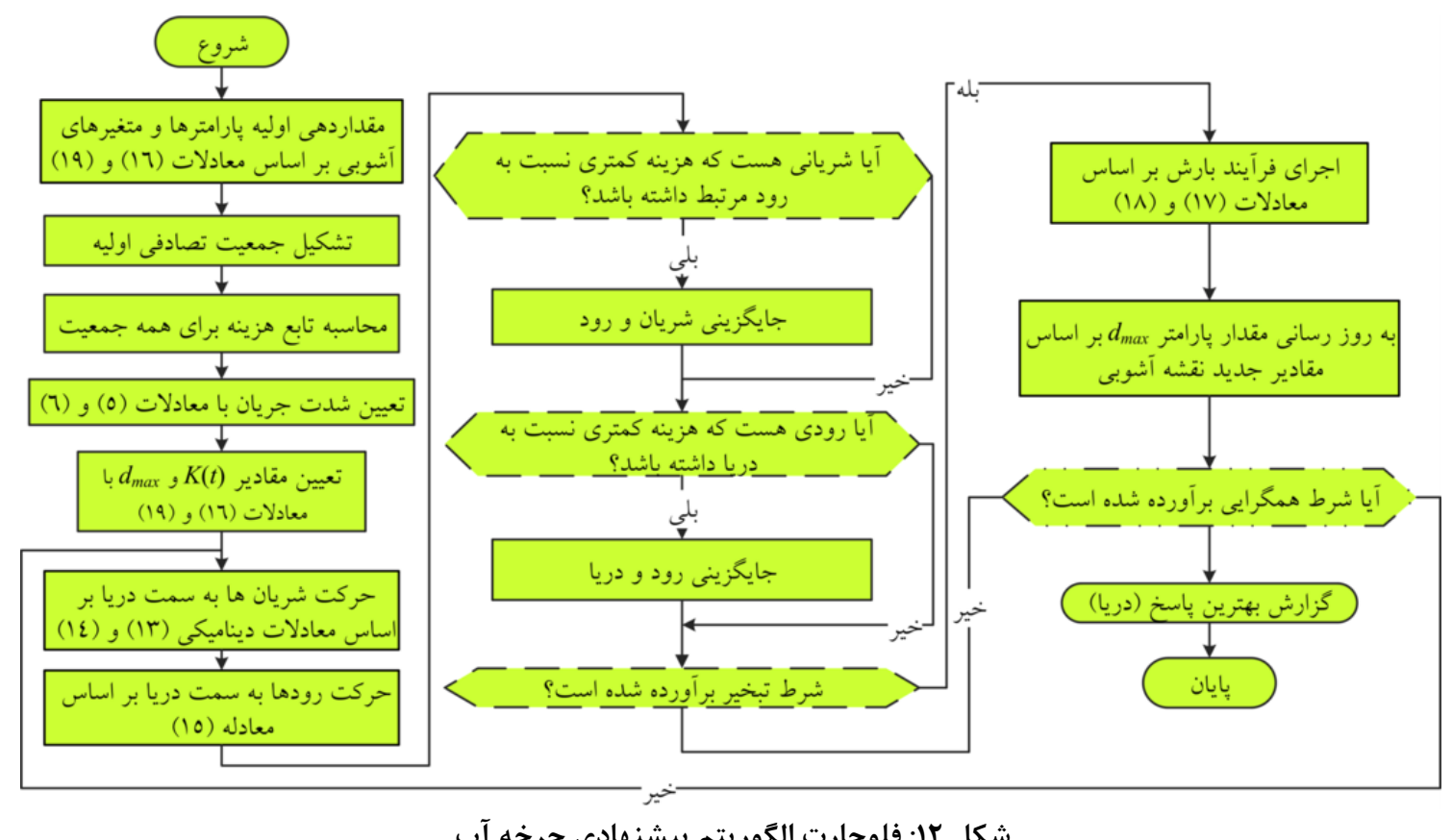

شكل rا: فلوجارت الكَوريته پيشنهادى جرخه آب

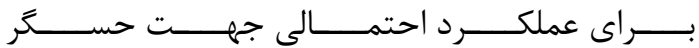
در نظر كرفته مىشوند.

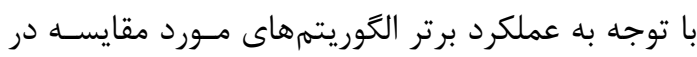

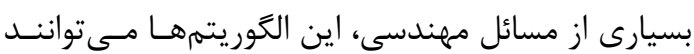

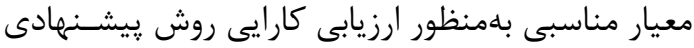

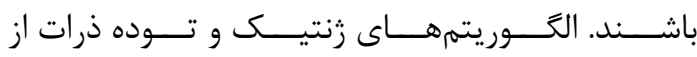

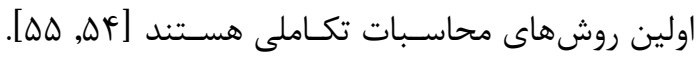

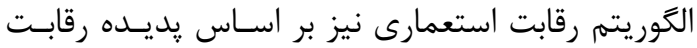

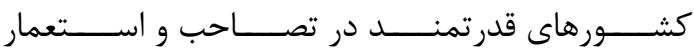

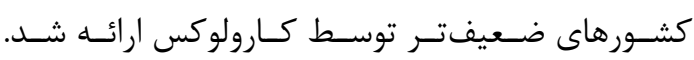
اين الكوريتم داراى يارامترهاى اوليه اى است كـهـ ابتـدا بايد توسط كاربر تعيين شوند. بـراى مطالعهـ سـاختار و وارئ

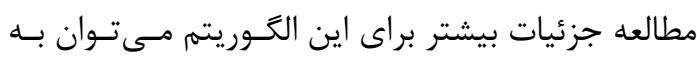

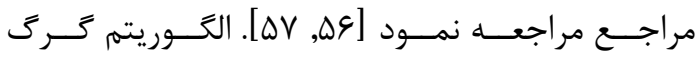

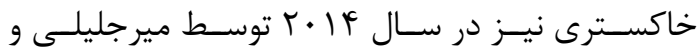

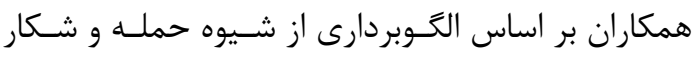

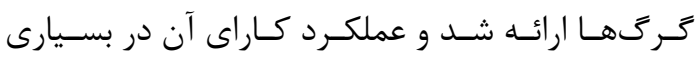

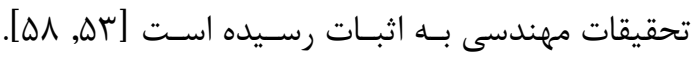

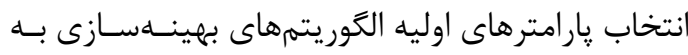

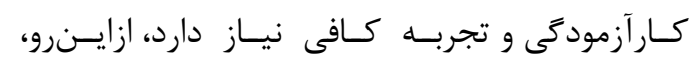

به منظور انجام ايـن ارزيـابىهـا، يارامترهـا و دادهــاى ورودى مسئله MCSDP بدينصورت انتخاب شده است:

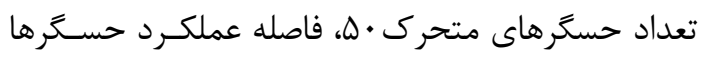

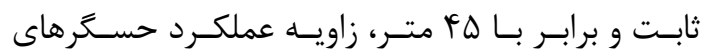

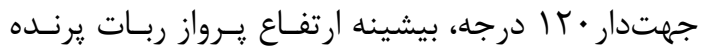

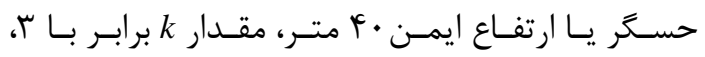
ميانكَين سرعت مجاز V براى ربات برابر ${ }^{\text {max }}$

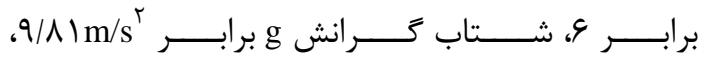
در مدل جهتدار حسكرى، متغيرهـاى مـورد جسـتجو

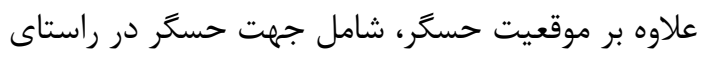

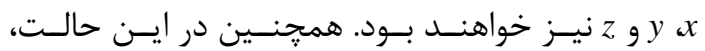
براى هر ربات حسكر متغير ارتفاعى h نيز اضافه كرديد.

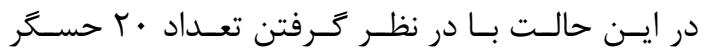
جهت دار مقدار : إرامترهاى متغير مورد جستجو برابر بـا

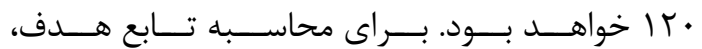
مدل احتمالى يوشش كه رويكردى واقـع كرايانـه اسـت، در نظر كرفته شده و راهحلهاى يافت شده الكَوريتمهــا بر اساس تابع هدف احتمالى يوشش بــه روز مسىشـوند.

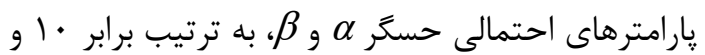

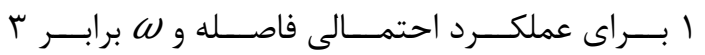




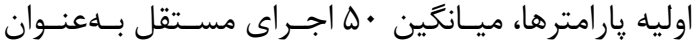

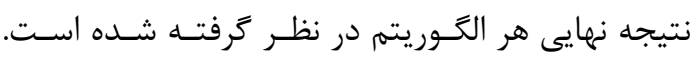

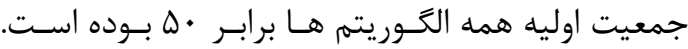

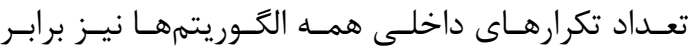

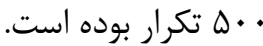
براى نحوه كدبندى الكَوريتم GA در حل مسئله، مطابق

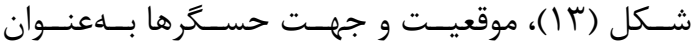

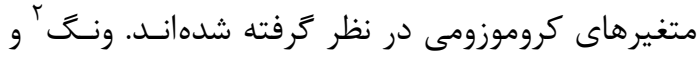

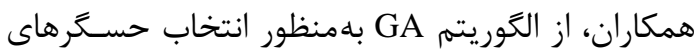

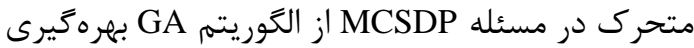

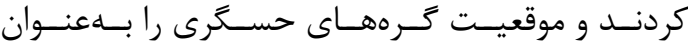

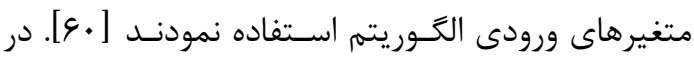

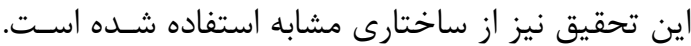

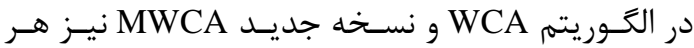
جريان بر اين اساس كد شده است. در ساير الكوريتمهــا نيز به دليل مشابهت ساختارى، جمعيت اوليه بهعنـوان آنان كشور، گرىى، يا يك ذره مطابق اين مدل ساخته شده و در مراحل بعد مطابق با عملكَرهاى هر الكوريتم تا زمـان

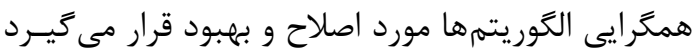

[द)] شرط يايان تمامى الكوريتههــا بـر اسـاس بــهـاركيرى

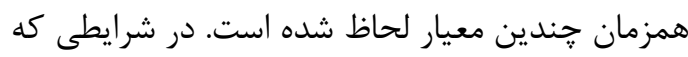

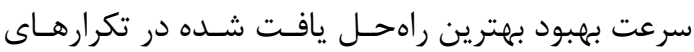
يبايى كمتر از يكهزارم باشد، يا تعداد تكرارها به بيشينه

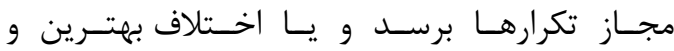

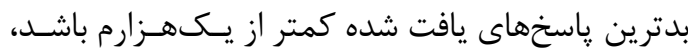

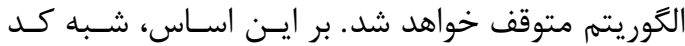

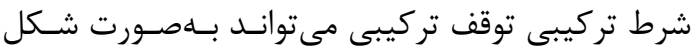

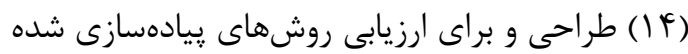

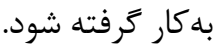

${ }^{2}$ Wang
با بهرهزيرى از تحليـل تـاگوجى ' [ه9]، مناسـبتـرين

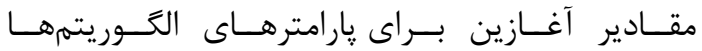
انتخاب شده است كه به علت محدوديت در صـفحات از ذكر جـدولهـاى آن خـوددارى شـده اسـت. در رِايـان تحليـل تـاكوجى، بهتــرين تنظيمـات الحَــوريتهمهـا در

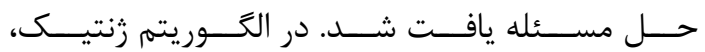
عملكَر انتخــاب مسـابقهاى، جمعيـت اوليـه • •ل (تعـداد

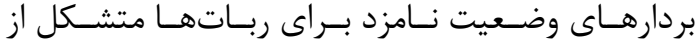

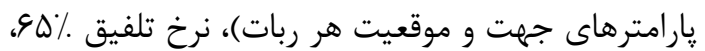

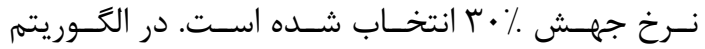
توده ذرات، جمعيت •له براى بردارهاى وضعيت رباتها، ضريب اينرسى برابر ا و ضرايب شتاب به ترتيـب بـراى براى برداي

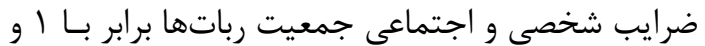

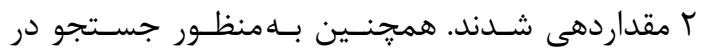
محدودهى متغيرهاى مسئله MCSDP بيشـينه سـرعت

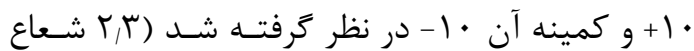

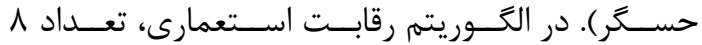
امبرياليست (بهترين بردارهاى وضعيت ممكن ربـاتهـا

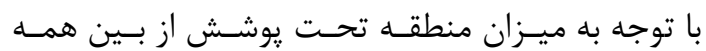
بردارهاى وضعيت اوليه)، ضريب همسانسازى بردارهاى وضعيت r، ضريب ميانكين هزينه كلونى بردارهاى اوليه

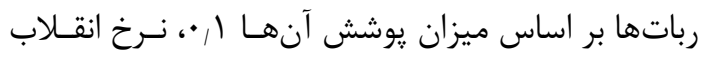
(ميزان جهش اعمال شده در متغيرهاى بردارهاى اوليسه

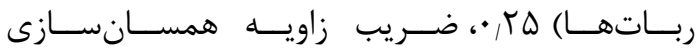

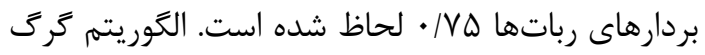

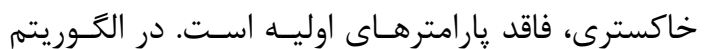

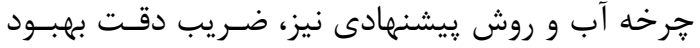

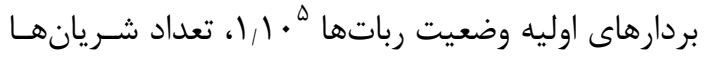
(بهترين ياسخ هاى زيربهينه مسئله MCSDP بر اساس

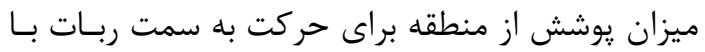

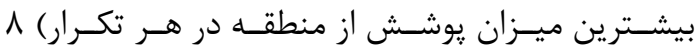

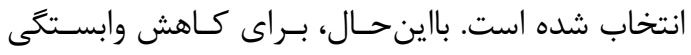
هرجه بيشتر الكوريتمها نسبت به نحوه انتخاب و مقــدار

${ }^{1}$ Taguchi 


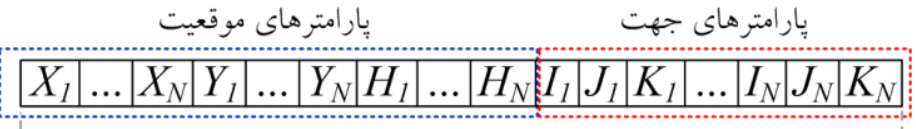

$6 \mathrm{~N}$

شكل با: مدل كروموزومى راهحلها براى مدل سهبعدى محيط

if the average improvement of best(i) is below 0.001 for $i=1: 500$ generations, check if maximum distance (best(i)-worst(i)) $<0.001$ break and return \{ best, mean, worst, std, time\} plot the convergence curve and display the found sensors else if the iteration $<500$, continue

شكل fl: شبه كد شرط يايان الكوريتمها

ييادهسازىهاى متوالى و مستقل اسـت. بـدين منظـور، نرخ موفقيت هر الكوريتم در توانايى جستجو و اكتشـاف

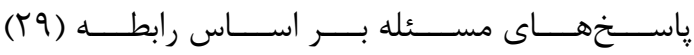
محاسبه مى گردد: $S r=100 \times\left[\Xi_{\text {best }} / \Theta_{\text {total }}\right]$ رابطه (rq) كه در اين رابطــ، ${ }^{\prime} \Xi_{\text {best }}$

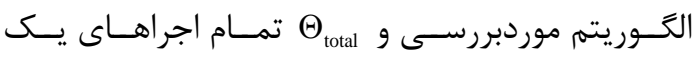

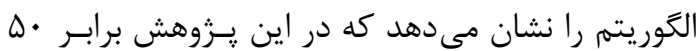

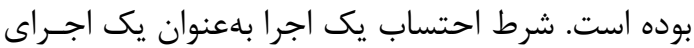
موفق مىتواند بر اساس رابطه ( • ب) بهدست آيد:

رابطه (r) موتى (r) $\sum_{e=1}^{\operatorname{Dim}}\left(P_{e}^{g b}-P_{e}^{B}\right)^{2} \leq\left(L_{\max }-L_{\min }\right) \times 10^{-1}$, در رابطه (צ))،

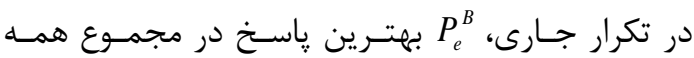
شبيهسازىها، Dim بعد مسئله،

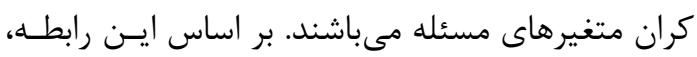

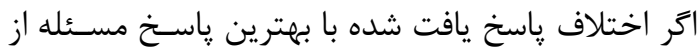
يك دهم كمتر باشد، اجراى جارى مىتواند بهعنوان يك ليك اجراى موفق محسوب شود.

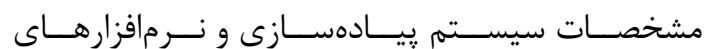

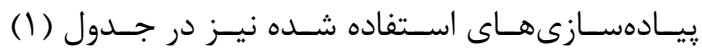
ارائه شده است. در اين زيادهسازىها از هيج نـرمافـزار و

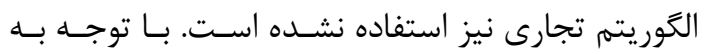

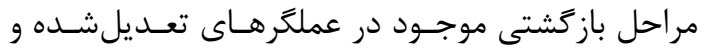

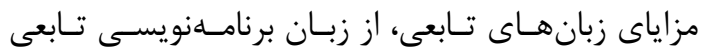

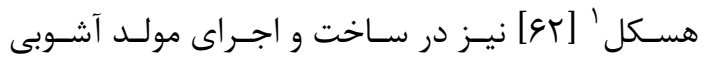
استفاده شده است.

جدول ا: جزئيات سيستم، زبان و نرمافزارهاى پييادهسازى

\begin{tabular}{|c|c|}
\hline جزئيات بيادهسازى & مشخصات \\
\hline $\begin{array}{l}\text { Pentium IV processor CPU, } 1.7 \\
\text { GHz, } 512 \text { MB RAM, Windows } 7\end{array}$ & مشخصات \\
\hline $\begin{array}{l}\text { MATLAB R2012a } \\
\text { Haskell, C++ }\end{array}$ & بربامهنويسى \\
\hline MATLAB, Hugs $98^{2}$ & 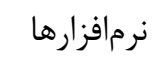 \\
\hline $\begin{array}{l}\text { GA, PSO, GWO, ICA, WCA, } \\
\text { MWCA }\end{array}$ & الخوريتمها \\
\hline
\end{tabular}

يكى از معيارهاى اسـتاندارد در ارزيـابى ميـزان كـارايى

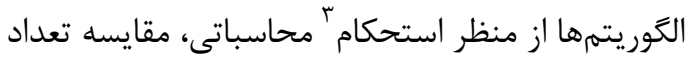

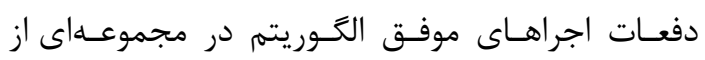

${ }^{1}$ Haskell

${ }^{2}$ Hugs 98 : http://haskell.org/hugs

${ }^{r}$ Robustness 
معيارهـاى بيـان شـده در ســرهاى آن جــدول اسـت.

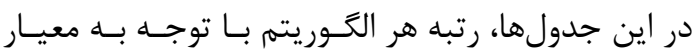
همان سطر بهصورت انديس مقادير تزارش شده است و

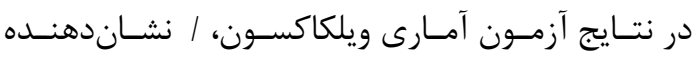

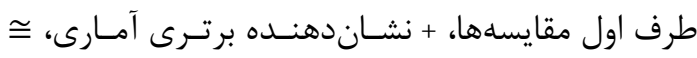

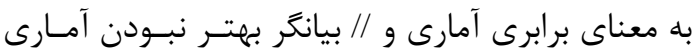

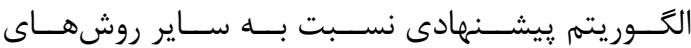
مورد مقايسه است.

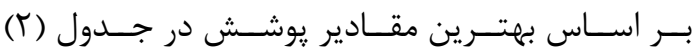

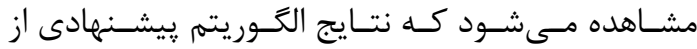
ديدكاه آمارى، در همه موارد، داراى اخـتلاف معنـادارى

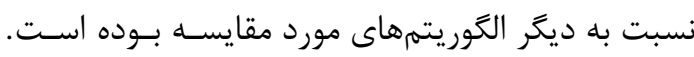
در مجموع •D اجراى مستقل، MWCA قادر به يوشش برد

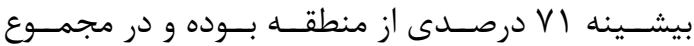

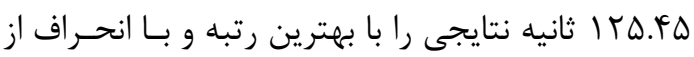

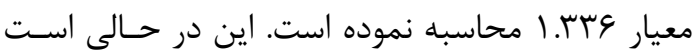
كه كارايى الكَوريتم WCA با توجه به مقادير انحـراف از معيار در رتبه ه و تنها بهتر از الكوريتم ICA بوده است.

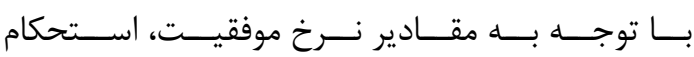

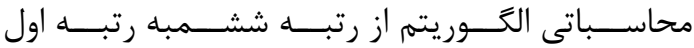
رسيده است. برترى نتايج بهدست آمده بـهدليـل بهبــود

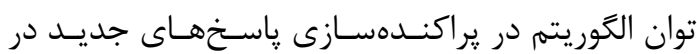
فضاى جستجو به كمك عملكرهاى تركيبى جديد است. بلموجب اصلاحات بهعمل آمده در عملكر متنوع سـازى،

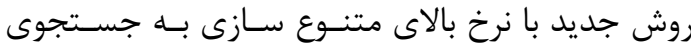

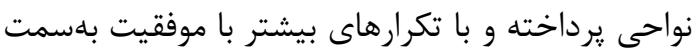
متمركز سازى ياسخها بِيش رفته است.
بلهنظور تحليل و مقايسه برترى آمارى نتايج الحَــوريته

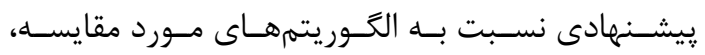

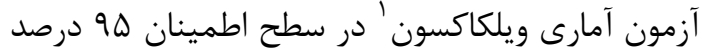

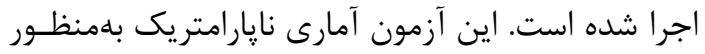

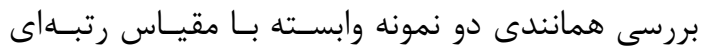
استفاده مىشود. در اين آزمون آمـارى، انـدازه اخـتلاف رتبه ها در نظر كرفتـه مسى شـود. از ايـن رو، مسى تـوان

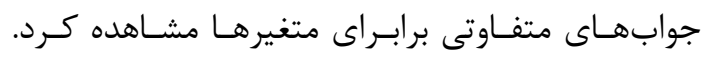

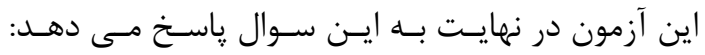

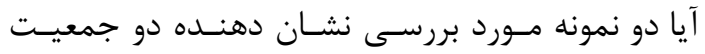

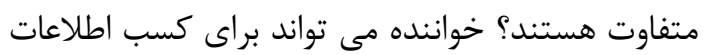

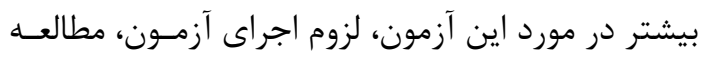

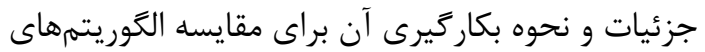
بهينهسازى به مرجع [بهات] مراجعه نمايد. براي مقايد.

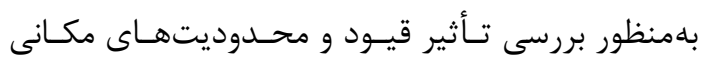

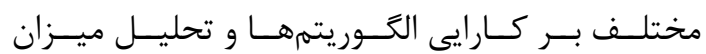

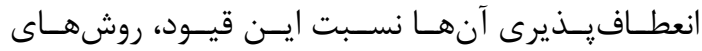

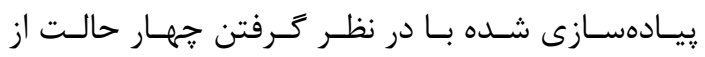

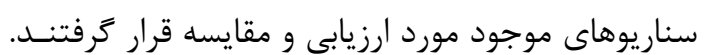

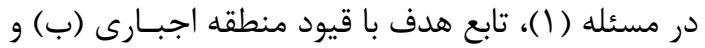

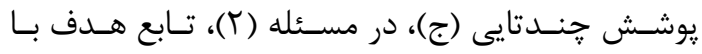

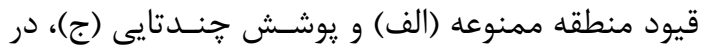

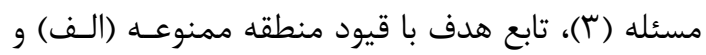

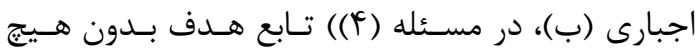

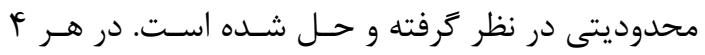

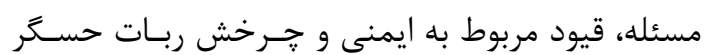
نيز لحاظ شده است.

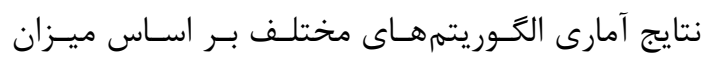

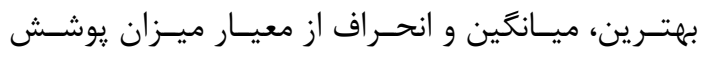

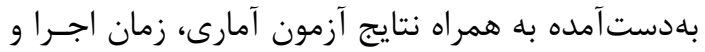

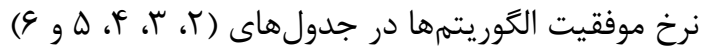

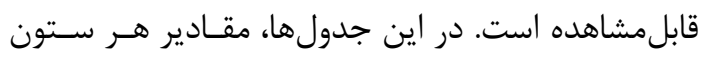

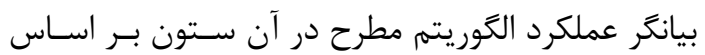

${ }^{1}$ Wilcoxon signed ranks test 
الكَوريتمى جديد و كارا براى جايابى و يوشش سهبعدى...

على اصغر حيدرى، فريد كريمىيور

جدول ب: بهترين، ميانگين و انحراف از معيار مقادير يوشش بلدست آمده در مجموع •ه اجرا و زمان محاسبات و

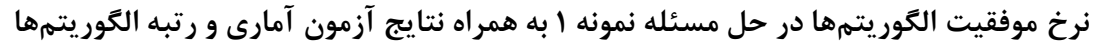

\begin{tabular}{|c|c|c|c|c|c|c|c|}
\hline GWO & PSO & GA & ICA & WCA & MWCA & معيار يوشش & مسئله \\
\hline$G V_{T}$ & $p q_{f}$ & $r \Lambda_{\varphi}$ & $F V_{\Delta}$ & $\Delta \Lambda_{r}$ & Vi, & بهترين & \multirow{6}{*}{1} \\
\hline $9 l^{t}$ & $r \varepsilon_{f}$ & $r V_{4}$ & $F r_{\Delta}$ & $\Delta r_{r}$ & $\varphi \Delta_{1}$ & ميانگين & \\
\hline $1,9 \wedge \Delta_{r}$ & $r_{/} \wedge \Delta \Delta_{r}$ & T,TYTr & ( & $r_{1} r_{\Delta}$ & 1, & انحراف از معيار & \\
\hline$\| \mu, r \Delta_{\mu}$ & $194,99_{0}$ & IVG, qr & $\mid \Delta F, g r_{r}$ & $\left.|r| \Delta\right|_{r}$ & $\mid r \omega_{1} r \Delta_{1}$ & زمان (ثانيه) & \\
\hline$\Delta \Lambda_{t}$ & $\operatorname{FF}_{\Delta}$ & $p q_{t}$ & $\Delta r_{r}$ & $f \cdot q$ & $q q_{1}$ & نرخ موفقيت & \\
\hline+ & + & + & + & + & 1 & آزمون آمارى & \\
\hline
\end{tabular}

جدول ؟: بهترين، ميانتين و انحراف از معيار مقادير :بوشش بلددست آمده در مجموع •ه اجرا و زمان محاسبات و

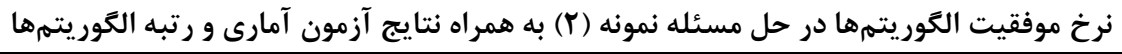

\begin{tabular}{|c|c|c|c|c|c|c|c|}
\hline GWO & PSO & GA & ICA & WCA & MWCA & معيار يوشش & مسئله \\
\hline$\varphi \Delta_{1}$ & $F V_{t}$ & & $F F_{0}$ & $\Delta \cdot r$ & $g F_{T}$ & بهترين & \multirow{6}{*}{$r$} \\
\hline$\Delta V_{T}$ & $f l_{0}$ & $r q_{4}$ & $\mathrm{Fr}_{F}$ & $r \Lambda_{r}$ & $\Delta q_{1}$ & ميانخين & \\
\hline l, & $r, q r r_{r}$ & $r_{1} \cdots r_{r}$ & $r_{1} \mid c q_{4}$ & $\left.r_{1}\right) \cdot \Lambda_{0}$ & $1, f \backslash \Lambda_{\mathrm{r}}$ & انحراف از معيار & \\
\hline $\mid F T, V F_{r}$. & $19 \wedge, \& \varphi_{\Delta}$. & $\mid \wedge r_{/} \Delta r_{\phi}$ & $191,9 T_{f}$ & $\| r \wedge \wedge \Delta_{r}$ & | & زمان (ثانيه) & \\
\hline$\varepsilon T_{1}$ & $r q_{f}$ & $r q_{t}$ & $\Delta r_{r}$ & $r \Lambda_{4}$ & ET & نرخ موفقيت & \\
\hline$/ /$ & + & + & + & + & I & آزمون آمارى & \\
\hline
\end{tabular}

مسئله (ז) دجار كاهش و از سوى ديخر زمان محاسبات

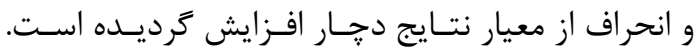

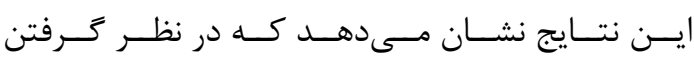
محدوديتهاى منطقه ممنوعه مىتوانـد بـار محاسـباتى نـاتي

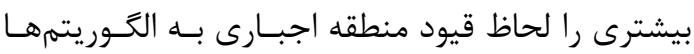

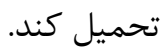

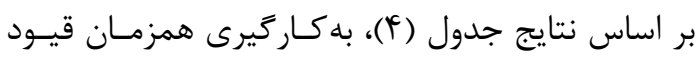

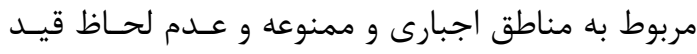

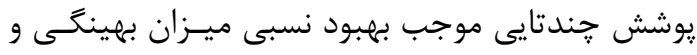

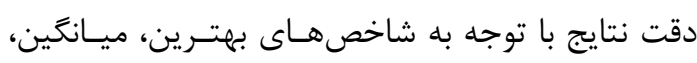
انحراف از معيار مقادير يوشش و زمان اجرا در مقايسه با بائ نائ مقادير نظير در مسائل ( (1) و (Y) كرديده است.

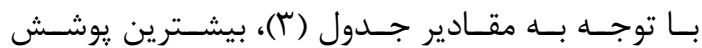

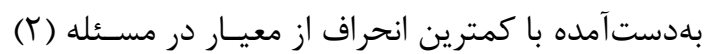
توسط الكوريتم GWO به دست آمده كه از عملكرهـائ

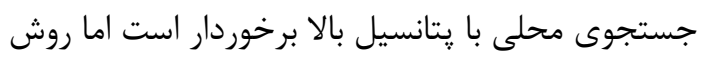

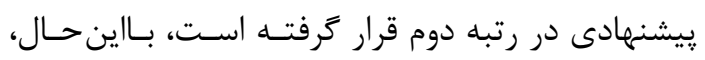

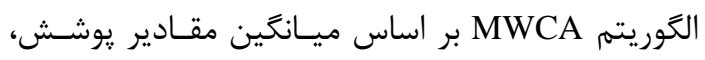

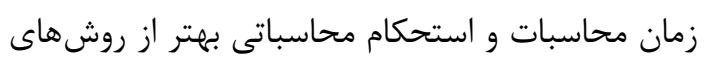

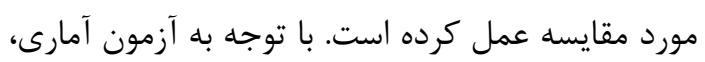

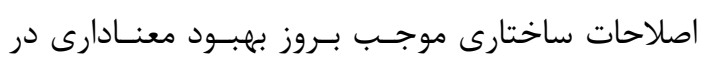

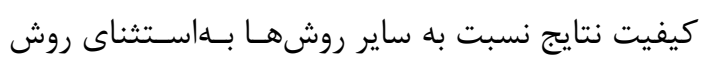

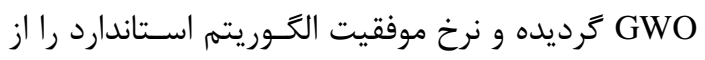

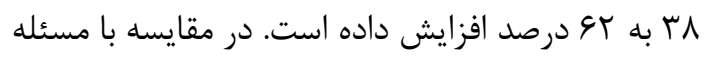

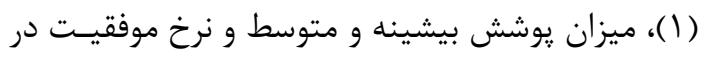




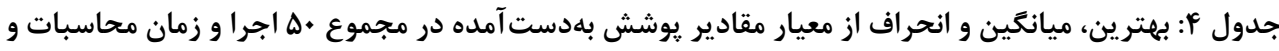

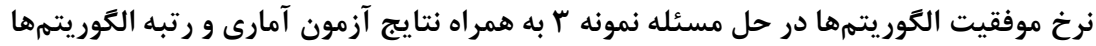

\begin{tabular}{|c|c|c|c|c|c|c|c|}
\hline GWO & PSO & GA & ICA & WCA & MWCA & معيار يوشش & مسئله \\
\hline $9 q_{r}$ & $\Delta / F$ & $F I_{4}$ & $f \varepsilon_{\Delta}$ & $9 I_{r}$ & $V r_{1}$ & بهترين & \multirow{6}{*}{ r } \\
\hline$q r_{r}$ & $i \wedge \wedge_{f}$ & $r q_{4}$ & $F r_{\Delta}$ & $\Delta F_{r}$ & EV & ميانگين & \\
\hline$r, F r \cdot r$ & $r_{j} \cdot r \Lambda_{f}$ & $r, r \cdot r_{r}$ & $r, \tau \cdot \varepsilon_{\Delta}$ & $r_{, q \mu r_{8}}$ & $1 \cdot \wedge \Delta_{1}$ & انحراف از معيار & \\
\hline $\mid r r, q \mu_{r}$ & $|\Delta \Lambda, \Gamma|_{\Delta}$ & $1 V \cdot, V q_{G}$ & $\mid f q_{/} \cdot \Delta_{r}$ & r & $\left\|F_{1}\right\| v_{1}$ & زمان (ثانيه) & \\
\hline$\Delta \Lambda_{T}$ & $r \varphi_{\Delta}$ & $F V_{f}$ & $\Delta \varepsilon_{r}$ & $\mathrm{Fr}_{4}$ & $q V_{1}$ & نرخ موفقيت & \\
\hline+ & + & + & + & + & I & آزمون آمارى & \\
\hline
\end{tabular}

مى تواند با دقت و سرعت محاسباتى بيشـترى

به ميانگين :وشش بيشترى از منطقه برسد.
الكوريتمهاى GA و PSO ICA بهطور تقريبـى بـا يـك سطح از اسـتحكام بـا ايـن مســـله روبــرو شـدهانـد. در

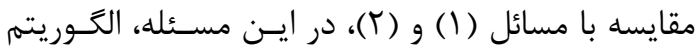

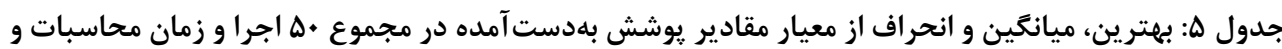

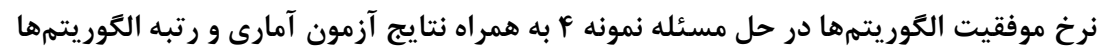

\begin{tabular}{|c|c|c|c|c|c|c|c|}
\hline GWO & PSO & GA & ICA & WCA & MWCA & معيار يوشش & مسئله \\
\hline$q q_{r}$ & $\Delta V_{F}$ & $1 \varphi_{4}$ & $\Delta \cdot \Delta$ & $G r_{r}$ & $\Lambda \cdot 1$ & بهترين & \multirow{6}{*}{$f$} \\
\hline$\mu_{r}$ & $p q_{p}$ & $\mathrm{Fr}_{4}$ & $F F_{\Delta}$ & $4 I^{4}$ & VI & ميانخين & \\
\hline $1,1 T \Lambda_{r}$ & $r, r \Delta q_{r}$ & $r, f q V_{f}$ & $r, r q r_{s}$ & $r_{/} \wedge \vee r_{\Delta}$ & $1 \cdot \cdot 1 r_{1}$ & انحراف از معيار & \\
\hline$\| \Lambda_{/} / T_{r}$ & $|f q,| r_{\Delta}$ & $19 \Lambda_{1} \cdot \Lambda_{4}$ & $|f|, q \mu_{f}$ & $\mid r q, f q_{r}$ & $111, r \Lambda_{1}$ & زمان & \\
\hline $9 l_{T}$ & $\Delta / F$ & $F V_{\Delta}$ & $\Delta q_{r}$ & $\mathrm{FF}_{4}$ & $V_{1}$ & نرخ موفقيت & \\
\hline // & + & + & + & $\cong$ & I & آزمون آمارى & \\
\hline
\end{tabular}

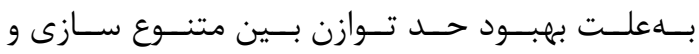

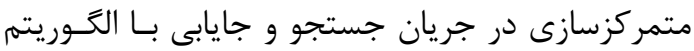

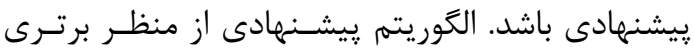

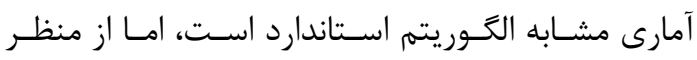

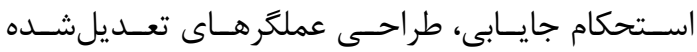
در الكوريتم جديد منجر به افزايش هب درصدى در نرخ

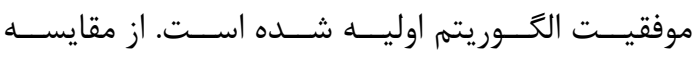

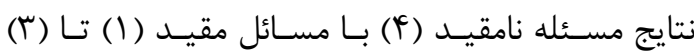

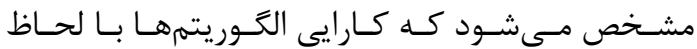

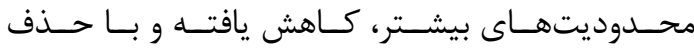

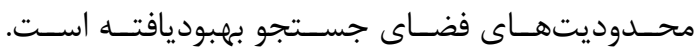
بهطور مثال، حداكثر يوشش در مســئله (أl) بـه ميـزان

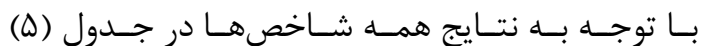

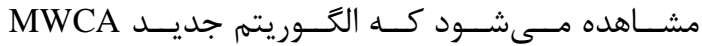

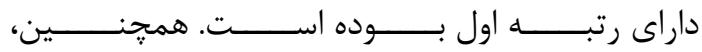

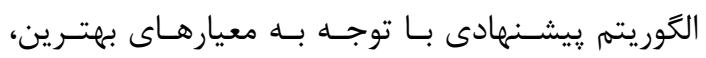
ميانخين و انحراف از معيار نتايج، توانسته اسـت ميـزان يوشش بيشترى را با دقت بهتر نسبت به سـاير روشهـا بهدست بياورد و بر اين اسـاس مشـاهده مسىشـود كـه بهـ

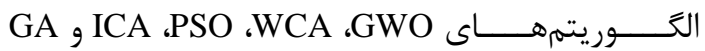

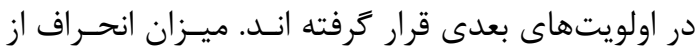

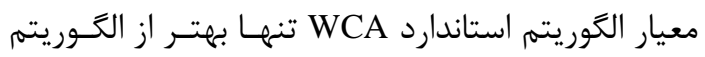
بوده، اما الگوريتم ICA بيشترين حد دقت رسـيده اسـت. ايسن مهـهم مسىتوانـد 


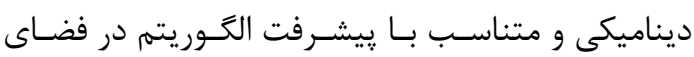
مسئله تعديل مى كردد.

براى تحليل و مقايسه نرخ همكَر ايى الكوريتمها، نمـودار

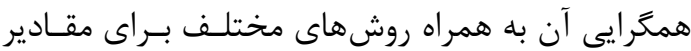

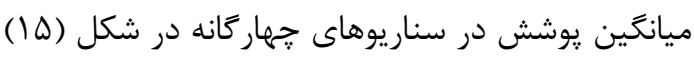
منعكس كرديده است.

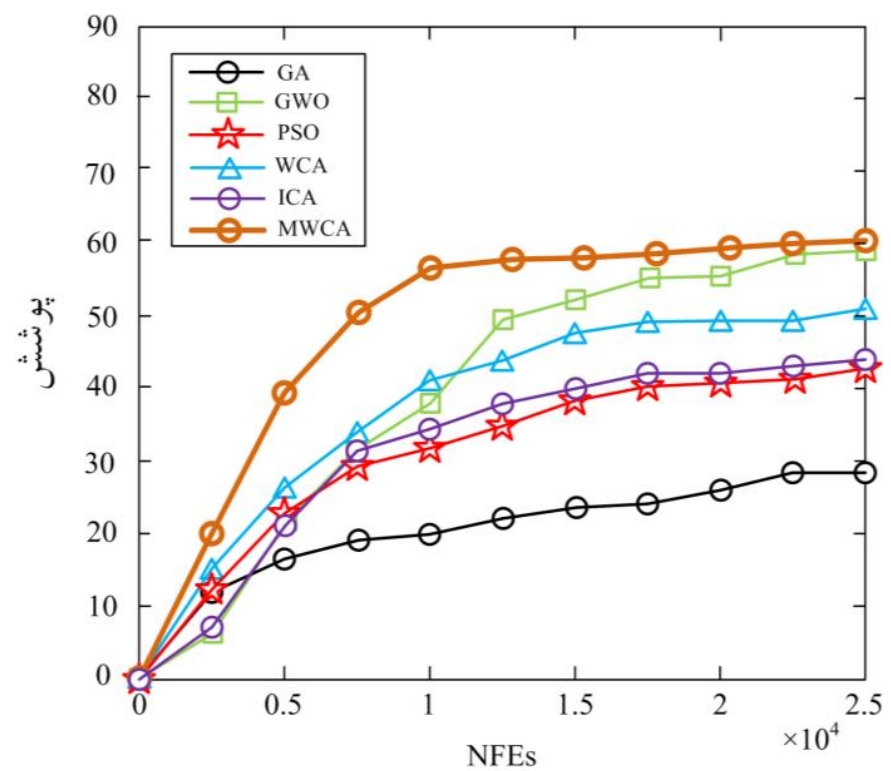

(ب) رفتار همخر ايى در مسئله (r)

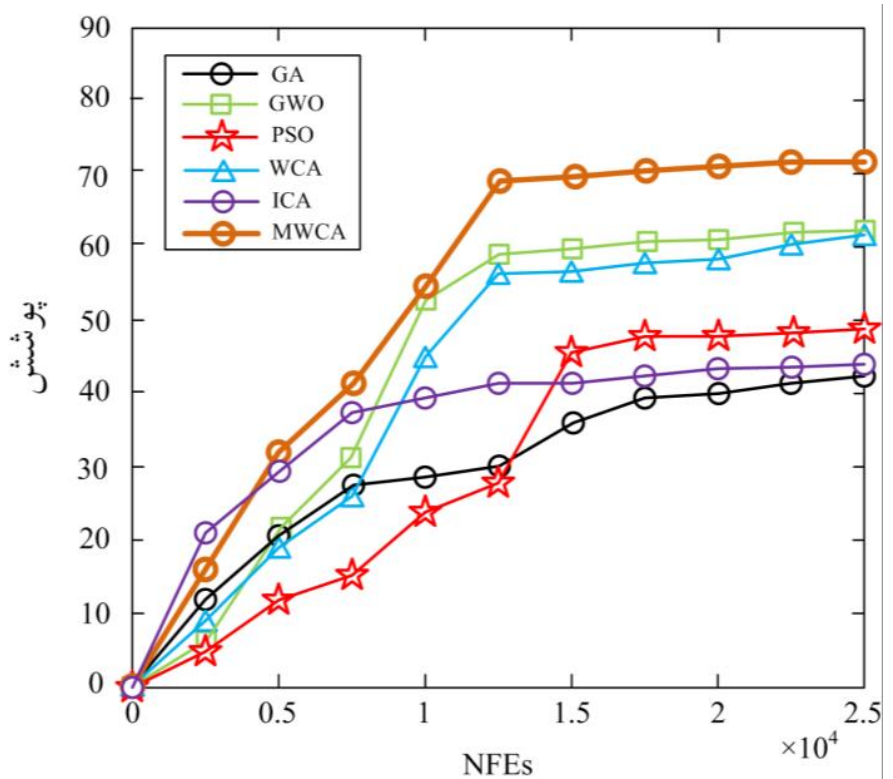

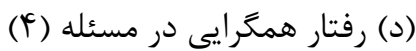

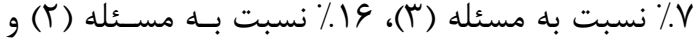

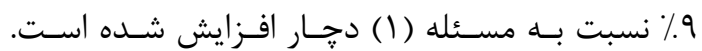
عملكرد و نتايج نزديك الكوريتمهاى MWCA و MWO

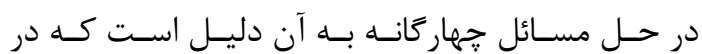

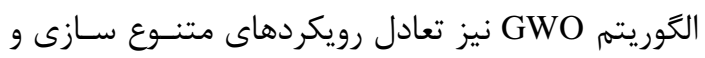

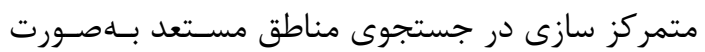

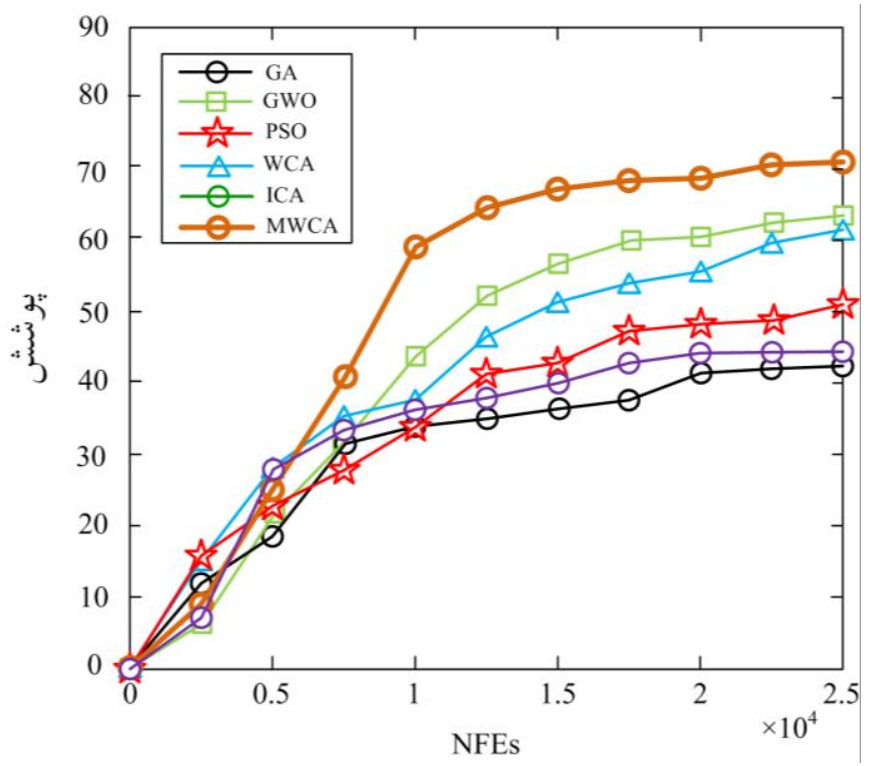

(الف) رفتار همخرايى در مسئله (1)

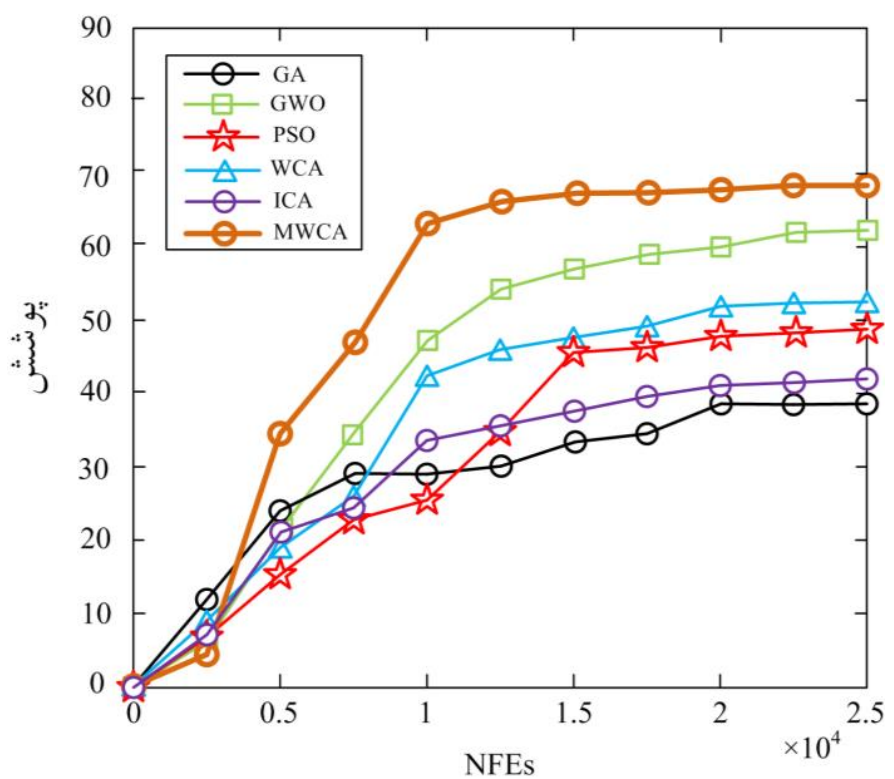

(ج) رفتار همخر ايى در مسئله (ب)

شكل ها: مقايسه نرخ همَّر ايى الكَوريتمها در حل سناريوهاى مورد آزمايش 
نرخ همگرايى و دقت روشها بوده كـه در قسـمت (ب)

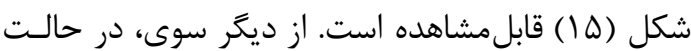

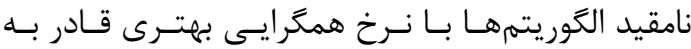
محاسبه يوشش بـودهانـد. بـا توجـهـ بــه نتـايج سـرعت همگر ايى در اين شكل مشخص مى شود كه بهكـارگيرى

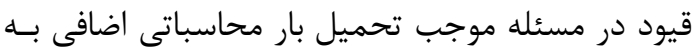
همه الخوريتمها مى كردد.

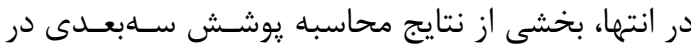

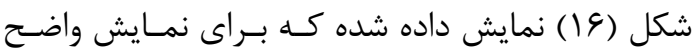
سطح جزئيات قابلمحاسبه بر مبنـاى رويكـرد جديسد و

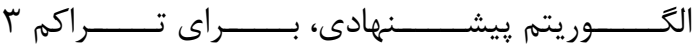
حسگر بلهدستآمده است.

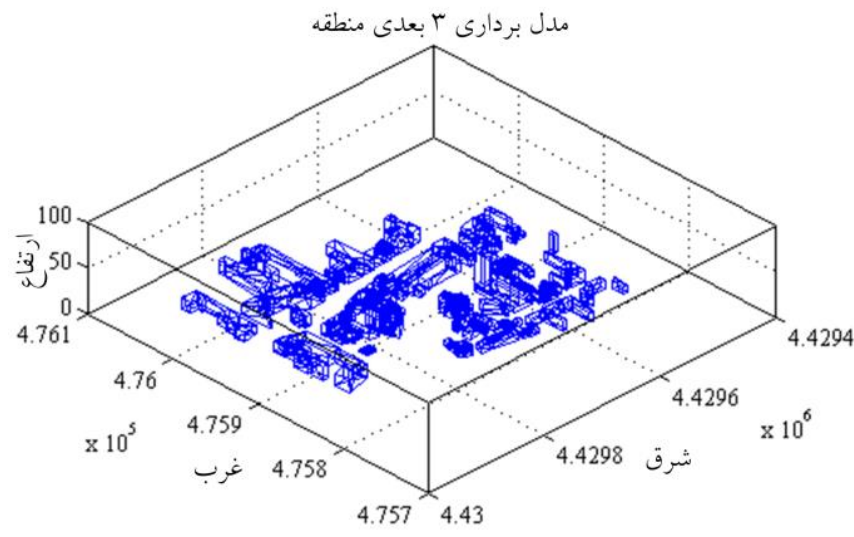
(ب) سراسر مدل بردارى منطقه ديد بِرسيكتيو پِلى گونهاى قابل ديد توسط حسگر

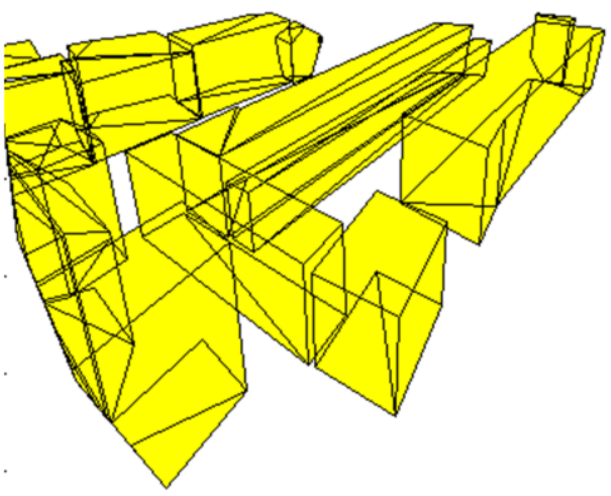

(د) بهترين ديد پرسيكتيو از داخل حسگر

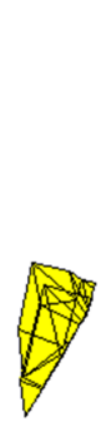

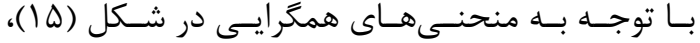

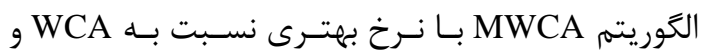

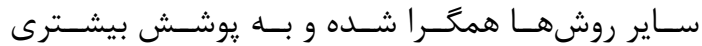
دست يافته است. همگًرايى روش GWO بهدليل ماهيت جستجوى ديناميكى آن به روش MWCA نزديك بوده و الگوريته GA نيز با كمترين سرعت همگرا شده است. دليل اين بهبود مىتواند بهتر بودن قدرت يراكندهسازى

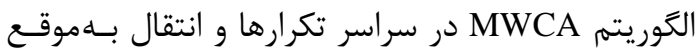

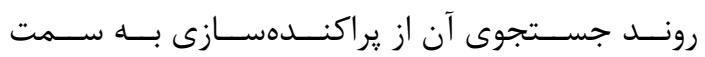

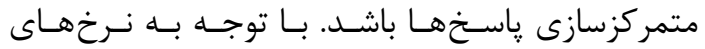

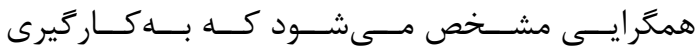
محدوديتهاى مكانى در مسئله (Y) موجب افت بيشـتر

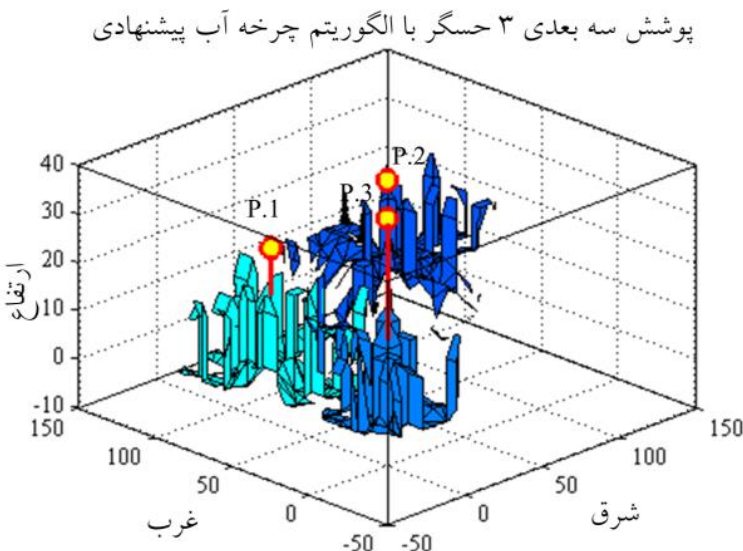

(الف) يوشش بيشينه و جايابى بهينه براى س حسگر نمايى از مناطق تحت بِوشش يك حسخر

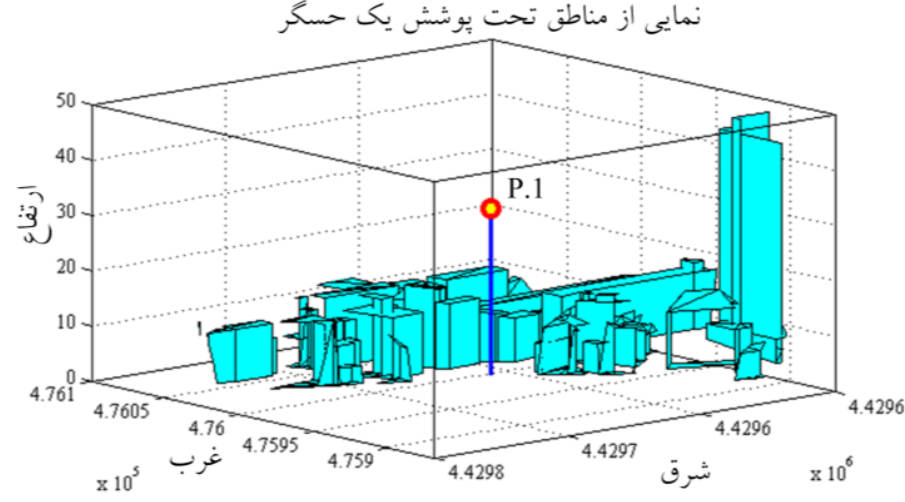

(ج) نمايى از حداكثر يوشش حسكر اول به مساحت ه.MFYV شكل 19ا: عملكرد رويكرد يِيشنهادى (الف): نتايج بيشترين يوشش ممكن، (ب): مدل بردارى منطقه، (ج): بخشى از

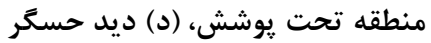




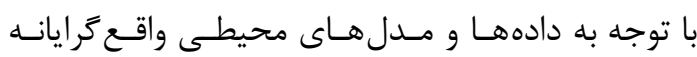

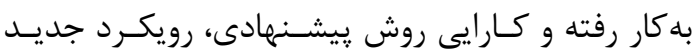

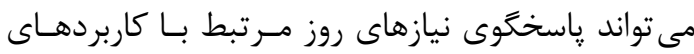

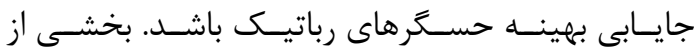

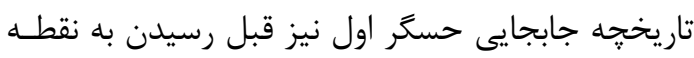

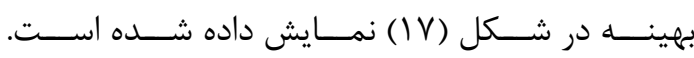

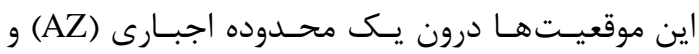

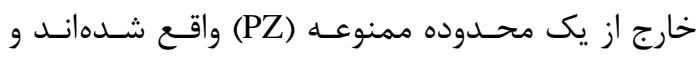

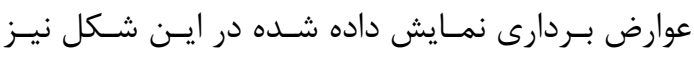
نشاندهنده ناحيه تحت يوشش ربات يس إز استقرار در

موقعيت بهينه است.
با توجه به سطح جزئيات هندسى نتـايج ايـن شـكل در

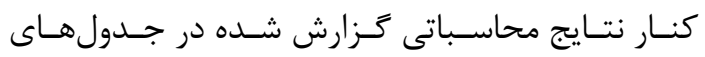

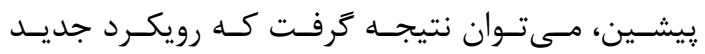
ارائه شده در اين تحقيق براى تعيسين جايسابى بهينـهـ و يوشش رباتها در محيط هاى بردارى قادر به محاسـبه

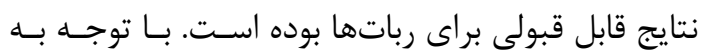

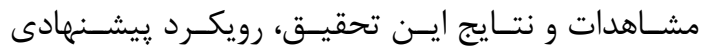

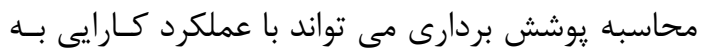

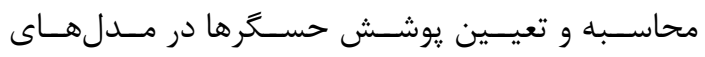

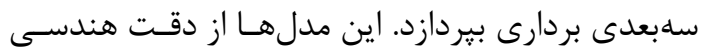

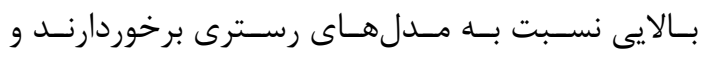
مجموعه اى از موقعيت هاى حسكر قبل از رودرون رسيدن به مكان بهينه

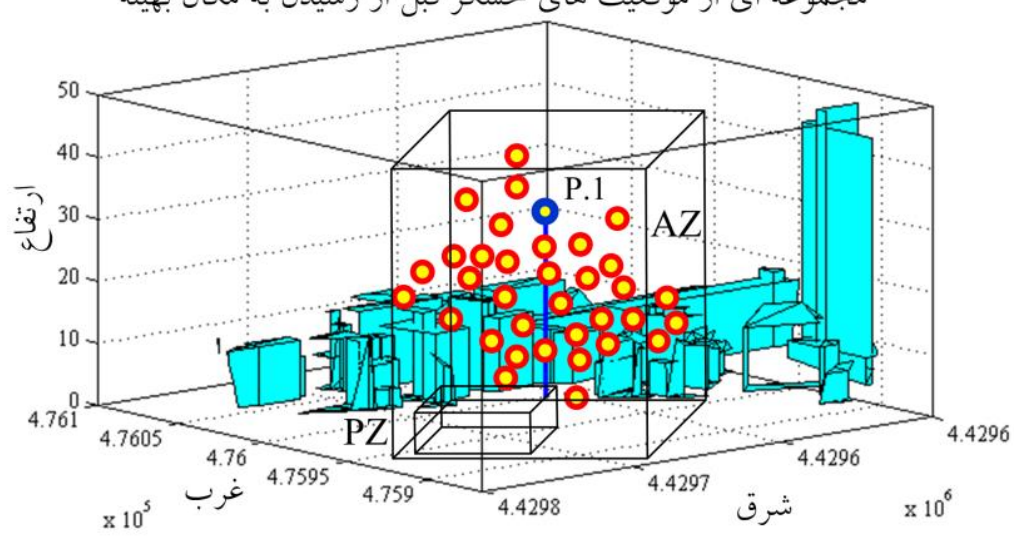

شكل Vا: تاريخجه جابجايى RAV قبل از رسيدن به موقعيت بهينه

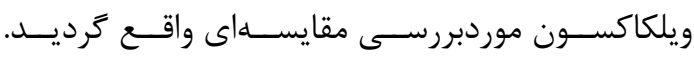

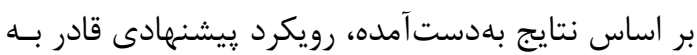
تعيين يوشش و جايابى بهينه كرههاى متحـرك بـوده و

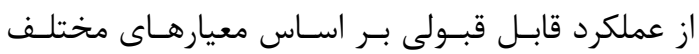

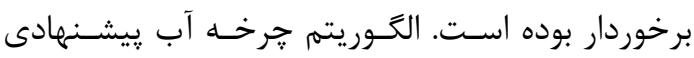

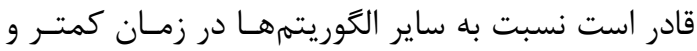

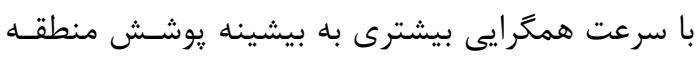

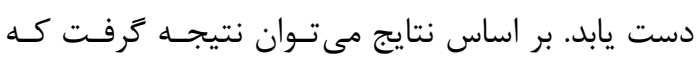

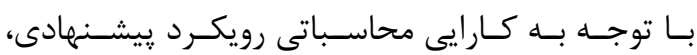

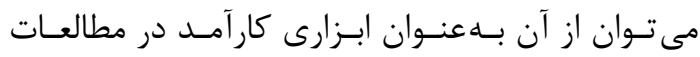

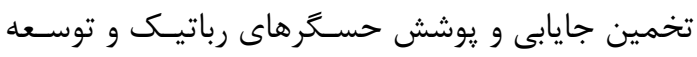

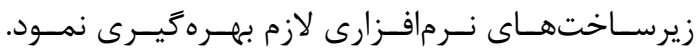

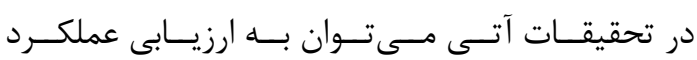

\section{9- نتيجه گيرى و وييشنهادها} در اين يزوهش، به ارائه يك رويكرد جديد و كـارا بـراى

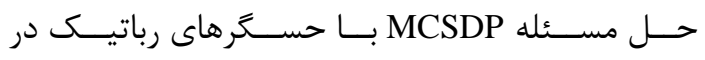
محيطهاى سهبعدى بردارى يرداخته شد. بدينمنظـور، رمان

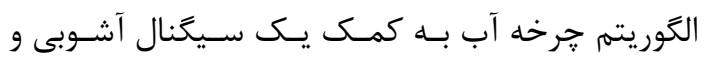

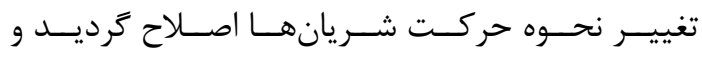

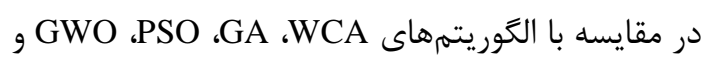

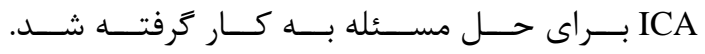

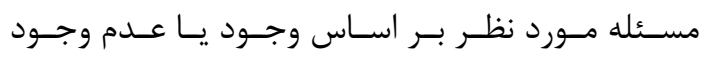

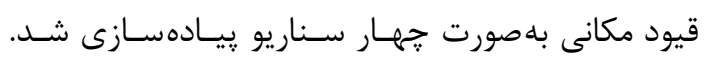

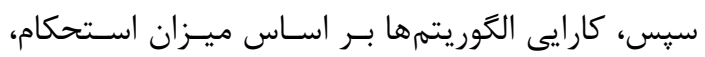

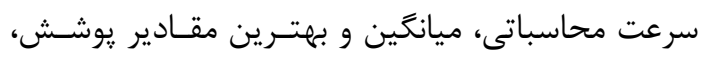

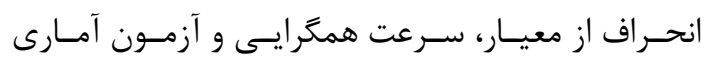




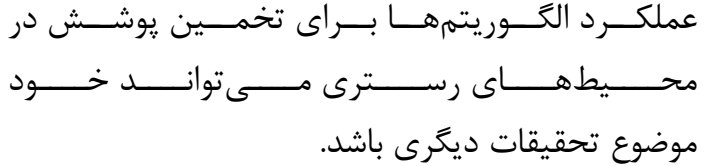

[1] P. Corke, S. Hrabar, R. Peterson, D. Rus, S. Saripalli, and G. Sukhatme, "Autonomous deployment and repair of a sensor network using an unmanned aerial vehicle," in Robotics and Automation, 2004. Proceedings. ICRA'04. 2004 IEEE International Conference on, 2004, pp. 36023608 .

[2] N. R. Ahmed, J. Cortes, and S. Martinez, "Distributed Control and Estimation of Robotic Vehicle Networks: An Overview of Part 2," IEEE Control Systems, vol. 36, pp. 18-21, 2016.

[3] J. Haugen and L. Imsland, "Monitoring moving objects using aerial mobile sensors," IEEE Transactions on Control Systems Technology, vol. 24, pp. 475-486, 2016.

[4] T. F. Villa, F. Gonzalez, B. Miljievic, Z. D. Ristovski, and L. Morawska, "An Overview of Small Unmanned Aerial Vehicles for Air Quality Measurements: Present Applications and Future Prospectives," Sensors, vol. 16, p. 1072, 2016.

[5] S. Hayat, E. Yanmaz, and R. Muzaffar, "Survey on unmanned aerial vehicle networks for civil applications: A communications viewpoint," IEEE Communications Surveys \& Tutorials, vol. 18, pp. 2624-2661, 2016.

[6] M. Saska, V. Vonásek, J. Chudoba, J. Thomas, G. Loianno, and V. Kumar, "Swarm distribution and deployment for cooperative surveillance by micro-aerial vehicles," Journal of Intelligent \& Robotic Systems, pp. 1-24, 2016.

[7] M. F. Mysorewala, D. O. Popa, and F. L. Lewis, "Multi-scale adaptive sampling with mobile agents for mapping of forest fires," Journal of Intelligent and Robotic Systems, vol. 54, pp. 535-565, 2009.

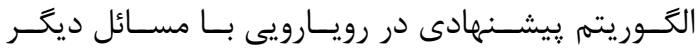

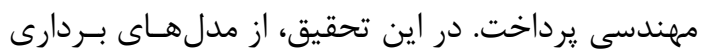

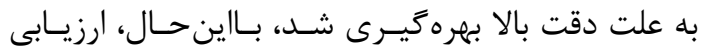

$$
\begin{aligned}
& \text { مراجع }
\end{aligned}
$$

[8] A. Pierson and M. Schwager, "Adaptive inter-robot trust for robust multi-robot sensor coverage," in Robotics Research, ed: Springer, 2016, pp. 167-183.

[9] C. Y. Ma, D. K. Yau, N. K. Yip, N. S. Rao, and J. Chen, "Stochastic steepest descent optimization of multiple-objective mobile sensor coverage," IEEE Transactions on Vehicular Technology, vol. 61, pp. 18101822, 2012.

[10] M. Rebai, H. Snoussi, F. Hnaien, and L. Khoukhi, "Sensor deployment optimization methods to achieve both coverage and connectivity in wireless sensor networks," Computers \& Operations Research, vol. 59, pp. 11-21, 2015.

[11]M. Vecchio and R. López-Valcarce, "Improving area coverage of wireless sensor networks via controllable mobile nodes: A greedy approach," Journal of Network and Computer Applications, vol. 48, pp. 1-13, 2015.

[12] S. N. Alam and Z. J. Haas, "Coverage and connectivity in three-dimensional networks with random node deployment," Ad Hoc Networks, vol. 34, pp. 157-169, 2015.

[13]F. Li, J. Luo, S. Xin, and Y. He, "Autonomous deployment of wireless sensor networks for optimal coverage with directional sensing model," Computer Networks, vol. 108, pp. 120-132, 2016.

[14] C. Zhu, C. Zheng, L. Shu, and G. Han, "A survey on coverage and connectivity issues in wireless sensor networks," Journal of Network and Computer Applications, vol. 35, pp. 619-632, 2012.

[15] C. Ozturk, D. Karaboga, and B. Gorkemli, "Probabilistic dynamic deployment of wireless sensor networks by artificial bee colony algorithm," Sensors, vol. 11, pp. 
6056-6065, 2011.

[16]X. Wang, S. Wang, and J.-J. Ma, "An improved co-evolutionary particle swarm optimization for wireless sensor networks with dynamic deployment," Sensors, vol. 7, pp. 354-370, 2007.

[17]Y. Yoon and Y.-H. Kim, "An efficient genetic algorithm for maximum coverage deployment in wireless sensor networks," IEEE Transactions on Cybernetics, vol. 43, pp. 1473-1483, 2013.

[18]R. Özdă̆ and A. Karc1, "Probabilistic dynamic distribution of wireless sensor networks with improved distribution method based on electromagnetism-like algorithm," Measurement, vol. 79, pp. 66-76, 2016.

[19]H. Zhu and Y. Shi, "Brain storm optimization algorithm for full area coverage of wireless sensor networks," in 2016 Eighth International Conference on Advanced Computational Intelligence (ICACI), 2016, pp. 14-20.

[20] G. Wang, L. Guo, H. Duan, L. Liu, and H. Wang, "Dynamic deployment of wireless sensor networks by biogeography based optimization algorithm," Journal of Sensor and Actuator Networks, vol. 1, pp. 86-96, 2012.

[21] R. V. Kulkarni and G. K. Venayagamoorthy, "Bio-inspired algorithms for autonomous deployment and localization of sensor nodes," IEEE Transactions on Systems, Man, and Cybernetics, Part C (Applications and Reviews), vol. 40, pp. 663-675, 2010.

[22]C.-W. Tsai, T.-P. Hong, and G.-N. Shiu, "Metaheuristics for the Lifetime of WSN: A Review," IEEE Sensors Journal, vol. 16, pp. 2812-2831, 2016.

[23] G. Werner-Allen, J. Johnson, M. Ruiz, J. Lees, and M. Welsh, "Monitoring volcanic eruptions with a wireless sensor network," in Proceeedings of the Second European Workshop on Wireless Sensor Networks, 2005., 2005, pp. 108-120.

[24]M. Argany, M. A. Mostafavi, V. Akbarzadeh, C. Gagné, and R. Yaagoubi,
"Impact of the quality of spatial 3D city models on sensor networks placement optimization," Geomatica, vol. 66, pp. 291305, 2012.

[25] J. Cortes, S. Martinez, T. Karatas, and F. Bullo, "Coverage control for mobile sensing networks," in Robotics and Automation, 2002. Proceedings. ICRA'02. IEEE International Conference on, 2002, pp. 13271332.

[26] M. Argany, M. A. Mostafavi, and C. Gagné, "Context-Aware Local Optimization of Sensor Network Deployment," Journal of Sensor and Actuator Networks, vol. 4, pp. 160-188, 2015.

[27] S. Temel, N. Unaldi, and O. Kaynak, "On deployment of wireless sensors on 3-D terrains to maximize sensing coverage by utilizing cat swarm optimization with wavelet transform," IEEE Transactions on Systems, Man, and Cybernetics: Systems, vol. 44, pp. 111-120, 2014.

[28] R. Shorey, A. Ananda, M. C. Chan, and W. T. Ooi, Mobile, wireless, and sensor networks: technology, applications, and future directions: John Wiley \& Sons, 2006.

[29] M. A. Guvensan and A. G. Yavuz, "On coverage issues in directional sensor networks: A survey," Ad Hoc Networks, vol. 9, pp. 1238-1255, 2011.

[30]H. Ma, X. Zhang, and A. Ming, "A coverage-enhancing method for $3 \mathrm{~d}$ directional sensor networks," in INFOCOM 2009, IEEE, 2009, pp. 2791-2795.

[31]G. Wang, G. Cao, and T. F. La Porta, "Movement-assisted sensor deployment," IEEE Transactions on Mobile Computing, vol. 5, pp. 640-652, 2006.

[32]Y. Wang and G. Cao, "On full-view coverage in camera sensor networks," in INFOCOM, 2011 Proceedings IEEE, 2011, pp. 1781-1789.

[33] v. Akbarzadeh, C. Gagn'e, M. Parizeau, and M. A. Mostafavi, "Black-box Optimization of Sensor Placement with Elevation Maps and Probabilistic Sensing Models," 
presented at the International Symposium on Robotic and Sensors Environment, ROSE, 2011.

[34] M. Argany, M. A. Mostafavi, F. Karimipour, and C. Gagné, "A GIS Based Wireless Sensor Network Coverage Estimation and Optimization: A Voronoi Approach," A Voronoi Approach. Transacton on Computational Sciences Journal, vol. 14, pp. 151-172, 2011.

[35]M. Argany, M. A. Mostafavi, V. Akbarzadeh, C. Gagné, and R. Yaagoubi, "Impact of the quality of spatial 3D city models on sensor networks placement optimization," GEOMATICA, vol. 66, p. 291-305, 2012.

[36] A. Hossain, P. Biswas, and S. Chakrabarti, "Sensing models and its impact on network coverage in wireless sensor network," in 2008 IEEE Region 10 and the Third international Conference on Industrial and Information Systems, 2008, pp. 1-5.

[37]X. Chen, K. Makki, K. Yen, and N. Pissinou, "Sensor network security: a survey," IEEE Communications Surveys \& Tutorials, vol. 11, pp. 52-73, 2009.

[38] J. C. Lee, V. C. Leung, K. H. Wong, J. Cao, and H. C. Chan, "Key management issues in wireless sensor networks: current proposals and future developments," IEEE Wireless Communications, vol. 14, pp. 76-84, 2007.

[39] V. Akbarzadeh, C. Gagné, M. Parizeau, M. Argany, and M. A. Mostafavi, "Probabilistic sensing model for sensor placement optimization based on line-of-sight coverage," IEEE Transactions on Instrumentation and Measurement, vol. 62, pp. 293-303, 2013.

[40]H. Eskandar, A. Sadollah, A. Bahreininejad, and M. Hamdi, "Water cycle algorithm-A novel metaheuristic optimization method for solving constrained engineering optimization problems," Computers \& Structures, vol. 110, pp. 151-166, 2012.

[41] J. F. Blinn and M. E. Newell, "Texture and reflection in computer generated images,"
Communications of the ACM, vol. 19, pp. 542-547, 1976.

[42] D. Hoiem, A. A. Efros, and M. Hebert, "Putting objects in perspective," International Journal of Computer Vision, vol. 80, pp. 3-15, 2008.

[43] J. D. Foley and A. Van Dam, Fundamentals of interactive computer graphics vol. 2: Addison-Wesley Reading, MA, 1982.

[44]M. Leonov, "Polyboolean library," Polyboolean library, 2004.

[45] B. Naylor, "Binary space partitioning trees as an alternative representation of polytopes," Computer-Aided Design, vol. 22, pp. 250-252, 1990.

[46] E. Besada-Portas, L. de la Torre, M. Jesus, and B. de Andrés-Toro, "Evolutionary trajectory planner for multiple UAVs in realistic scenarios," IEEE Transactions on Robotics, vol. 26, pp. 619-634, 2010.

[47] A. A. Heidari, R. A. Abbaspour, and A. R. Jordehi, "Gaussian bare-bones water cycle algorithm for optimal reactive power dispatch in electrical power systems," Applied Soft Computing, vol. 57, pp. 657671, 2017.

[48] A. Sadollah, H. Eskandar, A. Bahreininejad, and J. H. Kim, "Water cycle algorithm with evaporation rate for solving constrained and unconstrained optimization problems," Applied Soft Computing, vol. 30, pp. 58-71, 2015.

[49] A. Sadollah, H. Eskandar, A. Bahreininejad, and J. H. Kim, "Water cycle algorithm for solving multi-objective optimization problems," Soft Computing, vol. 19, pp. 2587-2603, 2015.

[50] A. A. Heidari, R. A. Abbaspour, and A. R. Jordehi, "An efficient chaotic water cycle algorithm for optimization tasks," Neural Computing and Applications, vol. 28, pp. 57-85, 2017.

[51] Y. Shi and R. C. Eberhart, "Empirical study of particle swarm optimization," in Evolutionary Computation, 1999. CEC 99. 
الكَوريتمى جديد و كارا براى جايابى و يوشش سهبعدى...

على اصغر حيدرى، فريد كريمىيور

Proceedings of the 1999 Congress on, 1999.

[52]M. Mahdavi, M. Fesanghary, and E. Damangir, "An improved harmony search algorithm for solving optimization problems," Applied mathematics and computation, vol. 188, pp. 1567-1579, 2007.

[53] S. Mirjalili, S. M. Mirjalili, and A. Lewis, "Grey wolf optimizer," Advances in Engineering Software, vol. 69, pp. 46-61, 2014.

[54]A. A. Heidari and M. R. Delavar, "A Modified Genetic Algorithm for Finding Fuzzy Shortest Paths in Uncertain Networks," Int. Arch. Photogramm. Remote Sens. Spatial Inf. Sci., vol. XLI-B2, pp. 299304, 2016.

[55]A. A. Heidari, S. S. Mirvahabi, and S. Homayouni, "An Effective Hybrid Support Vector Regression with Chaos-Embedded Biogeography-Based Optimization Strategy for Prediction of Earthquake-Triggered Slope Deformations," Int. Arch. Photogramm. Remote Sens. Spatial Inf. Sci., vol. XL-1/W5, pp. 301-305, 2015.

[56] M. A. Ardeh, M. B. Menhaj, E. Esmailian, and H. Zandhessami, "EXPLICA: An Explorative Imperialist Competitive Algorithm based on the notion of Explorers with an expansive retention policy," Applied Soft Computing, vol. 54, pp. 74-92, 2017.

[57]T. Niknam, E. T. Fard, N. Pourjafarian, and A. Rousta, "An efficient hybrid algorithm based on modified imperialist competitive algorithm and K-means for data clustering," Engineering Applications of Artificial
Intelligence, vol. 24, pp. 306-317, 2011.

[58]A. A. Heidari and P. Pahlavani, "An efficient modified grey wolf optimizer with Lévy flight for optimization tasks," Applied Soft Computing, vol. 60, pp. 115-134, 2017.

[59]G. Taguchi, Introduction to quality engineering: designing quality into products and processes, 1986.

[60] X. Wang, S. Wang, and D. Bi, "Dynamic sensor nodes selection strategy for wireless sensor networks," in Communications and Information Technologies, 2007. ISCIT'07. International Symposium on, 2007, pp. 1137-1142.

[61]X. Bai, S. Li, C. Jiang, and Z. Gao, "Coverage optimization in wireless mobile sensor networks," in Wireless Communications, Networking and Mobile Computing, 2009. WiCom'09. 5th International Conference on, 2009, pp. 1-4.

[62] K. Hammond and G. Michaelson, Research directions in parallel functional programming: Springer Science \& Business Media, 2012.

[63] J. Derrac, S. García, D. Molina, and F. Herrera, "A practical tutorial on the use of nonparametric statistical tests as a methodology for comparing evolutionary and swarm intelligence algorithms," Swarm and Evolutionary Computation, vol. 1, pp. 3$18,2011$. 


\title{
A Novel and Efficient Algorithm for three-dimensional Coverage and Deployment of Aerial Robots in Vector Spaces
}

\author{
Ali Asghar Heidari ${ }^{1}$, Farid Karimipour ${ }^{* 2}$ \\ 1- PhD student in GIS, School of Surveying and Geospatial Eng., College of Eng., University of Tehran \\ 2- Assistant professor, School of Surveying and Geospatial Eng., College of Eng., University of Tehran
}

\begin{abstract}
The maximum coverage sensor deployment problem has attracted researchers of engineering sciences always as one of the fundamental phases in developing of communication and geospatial infrastructures. In this research, a novel strategy is proposed to tackle the maximum coverage robotic sensor deployment task in 3D vector spaces. For this purpose, first, a geometric algorithm is developed in order to detect the covered areas. The water cycle optimization algorithm is utilized to maximize the sensor coverage. Then, to avoid the problem of premature convergence to local optima and to improve the efficiency and searching potential on the problem, an improved water cycle algorithm with dynamic operations and fewer parameters is designed and developed. With regard to several scenarios with different spatial constraints, the efficiency of the proposed algorithm is compared to other methods based on robustness, running time, best and average of the coverage results, standard deviation, convergence speed, and wilcoxon statistical test. The assessment of the results reveals the superior performance of the proposed approach by success rate of $73 \%$ and coverage of $80 \%$ in a $3 \mathrm{D}$ vector space.
\end{abstract}

Key words: Aerial robots, Deployment, Coverage, Vector space, Optimization, Water cycle algorithm 